\title{
THE RIGHTS OF PERSONS ACCUSED OF CRIME UNDER THE CANADIAN CONSTITUTION: A COMPARATIVE PERSPECTIVE
}

\section{A. Kenneth PyE*}

The Canadian Charter of Rights and Freedoms provides significant constitutional protections to persons accused of crime. ${ }^{1}$ The purpose of this article is to examine generally the nature of these rights and how they compare with the constitutional protections afforded to those accused of crimes in the United States. The breadth of the issues involved necessarily requires selectivity in this comparison.

\section{I}

\section{The Structure of the Protective Provisions}

The Charter enumerates specific "Legal Rights," some of which belong to everyone, $^{2}$ and some of which belong only to "[a]ny person charged with an offence," 3 "[a] witness," the Constitution of Canada which is declared to be "the supreme law of Canada." Any law that is inconsistent with a provision "is, to the extent of the inconsistency, of no force or effect." 7 The Charter applies both "to the Parliament and government of Canada . . . and . . to the legislature and government of each province ...."

The Charter clearly reflects a rejection of the views of opponents of a written bill of rights who have argued that the good judgment of Parliament and provincial legislatures provides sounder assurances for fundamental rights than a written document subject to the vagaries of interpretation by activist or conservative justices. ${ }^{9}$ The Charter places implicit faith in the courts to interpret and enforce the

Copyright $\mathbb{C} 1983$ by Law and Contemporary Problems

* Samuel Fox Mordecai Professor of Law, Duke University.

1. Constitution Act, 1982, ch. 1, §§ 7-14, 24. See also id. § 15.

2. Constitution Act, 1982, ch. 1, $\$ \$ 7-10,12$.

3. Id. $\S 11$.

4. Id. $\S 13$.

5. Id. $\S 14$.

6. Id. $\S 52$.

7. Id.

8. Id. $\S 32(1)(a)$.

9. See, e.g., Lord Lloyd of Hampstead, Do We Need a Bill of Rights?, 39 MOD. L. REv. 121 (1976); Russell, A Democratic Approach to Civil Liberties, 19 U. TORONTO L.J. 109 (1969); Schmeiser, Disadvantages of an Entrenched Canadian Bill of Rights, 33 SASK. L. Rev. 249 (1968); Smiley, The Case Against the Canadian Charter of Human Rights, 2 CAN. J. POL. SCI. 277 (1969). 
enumerated rights of the citizenry, ${ }^{10}$ despite a less than auspicious record of judicial leadership in civil liberties during the last two decades. ${ }^{11}$

Absent from the Charter is language used in the Canadian Bill of Rights that has been interpreted to limit significantly the rights apparently enumerated in that document. No longer is there language such as "have existed and shall continue to exist" which has been interpreted to permit civil liberties to be "frozen."12 The clear language of the Charter that inconsistent laws are "of no force or effect"13 should avoid the problems caused by the ambiguous language of the Canadian Bill of Rights that laws should "be so construed and applied as not to abrogate, abridge or infringe" rights. ${ }^{14}$ The application of the Charter to federal and pro-

10. See, e.g., Committe on the Constitution, The Canadian Bar association, Towards a New Canada (1978) [hereinafter cited as Towards a New Canada]; W. Tarnopolsky, The Canadian Bill of Rights (2d ed. 1975); Task Force on Canadian UntTy, A Future Together (1979); Brewin, The Canadian Constitution and a Bill of Rights, 31 SASK. L. REV. 251 (1966); Gibson, Charter or Chimera? A Comment on the Proposed Canadian Charter of Rights and Freedoms, 9 MAN. L.J. 363 (1979); McConnell, Some Comments on the Constitutional Amendment Bill: A Quasi-Presidential System for Canada?, 4 QUEENS L.J. 290 (1979); Tarnopolsky, A Bill of Rights and Future Constitutional Change, 57 CAN. B. REV. 626 (1979); Tarnopolsky, The Canadian Bill of Rights: From Diefenbaker to Drybones, 17 MCGILL L.J. 437 (1971); Tarnopolsky, $A$ Constitutionally Entrenched Charter of Human Rights_Why Now?? 33 SASK. L. REV. 247 (1968); Tarnopolsky, A New Bill of Rights in the Light of the Interpretation of the Present One by the Supreme Court of Canada, 1978 L. SOC'Y OF UPPER CAN., SPECIAl Lectures 161 [hereinafter cited as Tamopolsky Lecture]; Tarnopolsky, The Supreme Court and the Canadian Bill of Rights, 53 CAN. B. REV. 649 (1975).

11. Some opponents as well as proponents of an "entrenched" Bill of Rights seem to agree on the record of the courts in interpreting the Bill of Rights. See Schmeiser, The Role of the Court in Shaping the Relationship of the Individual to the State-The Canadian Supreme Court, 3 CAN.-U.S. L.J. 67, 69 (1980) ("Subject to a few exceptions, the Supreme Court has had a very negative influence on the development of individual rights in criminal law."). The Tarnopolsky articles and book, supra note 10, echo the same refrain. See Tamopolsky Lecture, supra note 10, at 166-84 (cases concisely summarized).

12. An Act for The Recognition and Protection of Human Rights and Fundamental Freedoms, reprinted in CAN. REV. STAT. app. III $\$ 1$ [hereinafter cited as CAN. BILL OF RIGHTS] ("It is hereby recognized and declared that in Canada there have existed and shall continue to exist without discrimination by reason of race, national origin, colour, religion or sex, the following human rights and fundamental freedoms . . . ."). This provision was interpreted by Ritchie, J., in Robertson and Rosetanni v. The Queen, 41 D.L.R.2d 485, 491 (Can. 1963) ("It is to be noted at the outset that the Bill of Rights is not concerned with 'human rights and fundamental freedoms' in any abstract sense, but rather with such 'rights and freedoms' as they existed in Canada immediately before the statute was enacted."). See P. HoGg, ConsTItUtional Law of Canada 437-38 (1977); Brandt, The Constitutional Amendment Act (Bill C-60), 17 U. W. ONT. L. REV. 267, 278 (1979); Gibson, supra note 10, at 368; see also Regina v. Miller, 70 D.L.R.3d 324 (Can. 1976); Regina v. Burnshine, 1975-1 S.C.R. 693 (Can. 1974); Attorney-General of Canada v. Lavell, 38 D.L.R.3d 481 (Can. 1973).

The Canadian Bill of Rights is, of course, a statute which does not limit the powers of the provinces.

13. Constitution Act, 1982, ch. $1, \S 52$.

14. CAN. BILL OF RIGHTS, supra note $12, \S 2$ :

Every law of Canada shall, unless it is expressly declared by an Act of the Parliament of Canada that it shall operate notwithstanding the Canadian Bill of Rights, be so construed and applied as not to abrogate, abridge or infringe or to authorize the abrogation, abridgment or infringement of any of the rights or freedoms herein recognized and declared, and in particular, no law of Canada shall be construed or applied so as to.

Both judges and commentators have attributed part of the reluctance of the Supreme Court to accord greater significance to the expressed rights in the Bill to this language. See Regina v. Drybones, 9 D.L.R.3d 473 (Can. 1969) (Cartwright, C.J.C., dissenting); Regina v. Gonzales, 32 D.L.R.2d 290, 292 (Can. 1962); Brandt, supra note 12, at 278; Tarnopolsky, A Constitutionally Entrenched Charter of Human Rights-Why Now?, supra note 10, at 247-48. Others have criticized the drafting of the Canadian Bill of Rights. See, e.g., D. SCHMEISER, Civil. LiberTIEs IN CANADa 52 (1964); Laskin, An Inquiny Into the Diefenbaker Bill of Rights, 37 CAN. B. REV. 77, 125 (1959). 
vincial governments as well as to Parliament and provincial legislatures ${ }^{15}$ should make it clear that citizens are protected from administrative action as well as from legislation. ${ }^{16}$ Unlike the Canadian Bill of Rights, the Charter provides protection at the prearrest stages of a criminal prosecution. ${ }^{17}$

The Charter recognizes that most fundamental rights are not absolute, but guarantees the enumerated rights "subject only to such reasonable limits prescribed by law as can be demonstrably justified in a free and democratic society."18 The inclusion of the requirement of "demonstrable justification" serves notice that the government has the burden of producing cogent cause if it seeks to limit rights in the interests of public safety, health, peace and security, morals, or other reasons. ${ }^{19}$

15. Constitution Act, 1982, ch. $1, \S 32$

16. The matter is not free from doubt, however. While Constitution Act, 1982, ch. $1, \S 52(1)$ provides that the Canadian Constitution is the supreme law of Canada, it provides only that any law not consistent with its provisions is, to the extent of the inconsistency, of no force or effect. There appears to be no provision similar to the 1978 Proposed Constitutional Amendment which said that certain rights should "be incapable of being alienated by the ordinary exercise of such legislative or other authority as may be conferred by law on its respective institutions of government." GovernMENT OF CANADA, ThE CONSTITUtional Amendment Bill (1978) [hereinafter cited as 1978 Proposals] (emphasis added). This language was clearly intended to overrule decisions such as that of Beetz, J., in Attorney-General of Canada v. Canard, 52 D.L.R.3d 548, 565 (Can. 1975). Beetz interpreted the Canadian Bill of Rights as not extending to matters of administration as distinguished from matters of legislation. Id. at 578; see also Brandt, supra note 12 , at 280 . The problem was concisely stated by Mr. David Copp, Vice-President, British Columbia Civil Liberties Association, in his testimony before the Parliamentary Committee:

First, Section 25 reasonably provides that laws that are inconsistent with the Charter are, to the extent of their inconsistency, inoperative. This does not go far enough, because many official standards which are not laws may be objectionable. For instance, a rule within a penitentiary could authorize a cruel punishment. In this case, a court asked to protect inmates in light of Section 12 of the Charter should have the power to strike down the offending tule [sic] without having to interfere with any statutes.

Accordingly, we suggest that Section 25 be amended to follow Section 26 of the discussion draft of August 22, which reads "that any law, order, regulation or rule that authorizes, forbids or regulates any activity in a manner inconsistent with the Charter may be declared inoperative."

22 Spec. Joint Comm. of the Senate and of the house of Commons on the Constitution of Canada, Minutes of Proceedings and Evidence of the Special Joint Committee of the Senate and of the House of Commons on the Constitution of Canada, 2d Parl., 1st Sess. 107 (1980) [hereinafter cited as Joint Committee Proceedings].

It is unfortunate that the Constitution does not include language similar to that suggested by Professor Tarnopolsky that would have made it crystal clear:

To the end that the paramountcy of this Charter be recognized and that full effect be given to the rights and freedoms herein proclaimed, any law, whether enacted before or after the coming into the effect of this Charter, and any administrative act in enforcement thereof, which is inconsistent with any provision of the Charter, except as specifically provided for, shall be inoperative and of no effect to the extent of the inconsistency.

Tarnopolsky, Bill of Rights and Future Constitutional Change, supro note 10, at 639. The Supreme Court has applied the Canadian Bill of Rights to police action denying an arrestee access to counsel. Hogan v. The Queen, 48 D.L.R.3d 427 (Can. 1974).

17. See, e.g., Constitution Act, 1982, ch. $1, \S 8$.

18. Id. $\$ 1$.

19. Laskin, The Canadian Constitutional Propasals, 1981 PuB. L. 340, 342. The 1980 Proposals § 1 provided that the freedoms set out were subject to "such reasonable limits as are generally accepted in a free and democratic society with a parliamentary system of government." GOVERNMENT OF CANADA, The Canadian Constitution: Proposed Resolution (1980) [hereinafter cited as 1980 Proposals]. The 1978 Proposals provided that:

Nothing in this Charter shall be held to prevent such limitations on the exercise or enjoyment of any of the individual rights and freedoms declared by this Charter as are justifiable in a free and demo- 
Rights declared to be fundamental in a written constitution are usually not subject to legislative modifications except through the process of amendment. But nations with traditions of parliamentary supremacy usually do not have written bills of rights. ${ }^{20}$ Canada has adopted a constitutional hybrid by which Parliament or the legislature of a province may "opt out" by expressly declaring in a law that it, or a provision thereof, shall operate notwithstanding any "Legal Rights" otherwise assured by the Charter. ${ }^{21}$ An American lawyer would be appalled by the notion that a state or the federal government could pass a law abridging a citizen's constitutional rights simply by providing that the law should operate without regard to the Constitution. However, the tradition of Parliamentary supremacy, the need to achieve acceptance by provinces where consensus concerning some of the provisions of the Charter may not exist, the existence of a similar provision in the Canadian Bill of Rights for over two decades, and the belief of experienced observers that Parliament, at least, would be unlikely to enact such a law, provide some assurances that the power may not be as significant as it appears at first glance. ${ }^{22}$ But because of the opt-out possibility, it is incorrect to say that the rights of an accused are "entrenched" by the Charter; "quasi-entrenchment" may be a more accurate description.

cratic society in the interests of public safety or health, the interests of the peace and security of the public, or the interests of the rights and freedoms of others, whether such limitations are imposed by law or by virtue of the construction or application of any law.

1978 PROPOSALS, supra note $16, \S 25$. The next year the Government of Canada proposed that all such limitations should be "prescribed by law" and that "national security" and "morals" were interests also justifying limitations. Federal Draft Proposals Discussed by First Ministers, Federal-Arovincial Conference of First Ministers on the Constitution, Doc. No. 800-010/037, Ottawa, Feb. 5-6, 1979 [hereinafter cited as 1979 FEDERAL Proposals], discussed in Gibson, supra note 10, at 385. Earlier proposals also contained limitations on governmental power less stringent than those in the new constitution. Article 3 of the 1971 VICTORIA CHARTER would have permitted such limitations on the exercise of the fundamental freedoms as are "reasonably justifiable" in a democratic society in the interests of public safety, order, health, or morals, of national security and freedoms of others. Government of Canada, Constrtutional Conference Proceedings 52 (1971) [hereinafter cited as 1971 Victoria Charter]. The 1972 Joint Committee on the Constitution recommended that any limitations should be only such "as are reasonably justifiable in a democratic society." SPEC. JoInt Comm. of the Senate and of THE House of Commons on The Constitution of Canada, Constitution of Canada: Final Report, 28th Parl., 4th Sess. 21 (1972) [hereinafter cited as 1972 JOINT COMMTTTEE REPORT]. In 1981, questions were raised concerning the meaning of "reasonable limits" and "demonstrably justified." 38 JOINT COMMITTEE PROCEEDINGS, supra note 16, at 41-42 (1981). The Minister of Justice indicated that the intent of the language was to meet the objections of Professor Tarnopolsky, Mr. Fairweather and others that such language was needed "to limit the scope of the legislature and Parliament in relation to the fundamental rights of Canadian citizens." Id. at 42 .

20. See McConnell, supra note 10, at 291.

21. Constitution Act, 1982 , ch. $1, \S 33$. Legislation is required renewing the decision to opt out at least every five years. Id. $\$ \S 33(3)-(5)$.

22. The Task Force on Canadian Unity proposed the power to opt out as one technique for achieving provincial acquiescence to the Charter. See TASK FORCE ON CANADIAN UNITY, supra note 10, at 108. Some commentators had urged such a provision as a compromise with the principle of legislative supremacy. See, e.g., P. HOGG, supra note 12, at 434. Others have regarded such language in a statute to "seriously undermine any notion that a Charter is intended to have paramount effect." Brandt, supra note 12 , at 278. No such provision was included in the 1980 Proposals, supra note 19. A provision permitting the provinces, but not the federal government, to opt out appeared in the 1979 FEDERAL PROPOSALS, supra note 19. No such proposals appeared in the 1972 JOINT COMMITIEE REPORT, supra note 19, the 1971 Victoria Charter, supra note 19, or the amendments to the constitution proposed in 1969. GOVERNment of Canada, The Constitution and the People of Canada (1969) [hereinafter cited as 1969 Proposals]. 
The division of powers between the federal and provincial governments and the power to opt out of observance of some of the rights guaranteed to those charged with a crime pose the possibility of significant confusion in the administration of criminal justice. The federal parliament has exclusive jurisdiction to enact legislation concerning criminal law and criminal procedure. ${ }^{23}$ Experienced observers think it unlikely that Parliament will attempt to avoid the protections of the Charter by opting out amendments to such statutes ${ }^{24}$ as the Criminal Code ${ }^{25}$ and the Canada Evidence Act. ${ }^{26}$ Likewise, it is reasonable to expect that the opting out provisions will be used sparingly, if at all, in the exercise of federal power to impose criminal penalties pursuant to its jurisdiction over matters such as trade and commerce, banking, national defense, and Indians. This should also be true for penalties imposed under the federal parliament's arguable "residual power" under section 91 of the British North America Act to make laws for the "peace, order, and good government of Canada" in areas not within the exclusive jurisdiction of the provinces. ${ }^{27}$

The provinces possess the power to enact legislation concerning "the administration of justice" and the "construction, maintenance, and organization of provincial courts." They may also pass laws under their "quasi-criminal" law jurisdiction ${ }^{28}$ derived from their power to legislate and enforce through penal sanction a number of specific matters of local concern. The provinces may be more likely to exercise the power to "opt out" in this area.

In an area where jurisdictional lines are blurred, there may be difficulties if a province opts out in a law establishing the procedures governing, for example, the investigation and prosecution in provincial courts of "quasi-criminal" conduct, ${ }^{29}$ and the federal parliament has not done so. Constitutional conflict may also arise between the provision providing protection against unreasonable search and seizure and the power of a province to enact legislation concerning "the administration of justice." The issue is posed whether a provincial statute can authorize a provincial law enforcement officer to conduct a search that would otherwise be

23. British North America Act, 1867, 30 \& 31 Vict., ch.3, $\S 91$ (27) [hereinafter cited as BNA]

24. See Tamopolsky Lecture, supra note 10, at 165; Gibson, supra note 10, at 387 ("Because the inclusion of such a 'flag' in any piece of legislation would inevitably stir up a great debate and controversy both in and out of Parliament, no government would employ the device lightly.").

25. Can. Rev. Stat. ch. C-34 (1970).

26. Can. Rev. Stat. ch. E-10 (1970).

27. See C. Griffiths, J. Klein \& S. Vendin-Jones, Criminal Justice in Canada 10 (1981).

28. BNA, supra note $23, \S 92(14)(15)$.

29. Professor McConnell has discussed the impact upon provinces who do not opt out:

[I] $\mathrm{t}$ is very possible that the interpretation of such an amendment in Canada could have an impact on "searches" in certain civil areas under provincial jurisdiction, such as compliance by home owners with sanitary conditions or building codes; the entitlement of welfare recipient's [sic] to further social assistance and inspecting conditions under which their children are being kept, and possibly the ascertainment of whether school children were using marijuana, which would at least in part concern the administration of schools. The search power might also arise in relation to provincial quasi-criminal offences relating to a wide range of matters.

McConnell, Unreasonable Searches and Seizures: A "Fourth Amendment" for Canoda?, 11 R.D.U.S. 155, 189 (1980); see also Regina v. Dignard, [1954] 2 D.L.R. 539 (Can.); Regina v. Millar, 10 W.W.R. (n.s.) 145 (Man. Ct. App. 1955). 
deemed unreasonable. ${ }^{30}$ Even if the lawfulness of such a search is determined to be governed by federal law enacted pursuant to the federal power to enact laws governing criminal procedure, an issue may be raised as to whether such an "unreasonable search," ostensibly authorized by the law of the province in which it took place and performed by an officer of that province, "would bring the administration of justice into disrepute"31 when the evidence was obtained in accordance with the unconstitutional provincial law. The conflicts may be complicated if a province has contracted with the Royal Canadian Mounted Police (RCMP) to provide local policing, ${ }^{32}$ or if the RCMP and local municipal forces are jointly investigating organized crime activities that may uncover violations of municipal, provincial, and federal law.

The narrow reach of federal preemption reflected in the "paramountcy" cases suggests an attitude of accommodation rather than confrontation in dealing with arguable conflict between federal and provincial differences in penal matters. ${ }^{33}$ In those provinces which depend upon the RCMP for policing, for example, adherence to the constitutional design might be facilitated by federal limitations upon the RCMP to assure that their behavior is consistent with the constitutional mandate, thereby affording the provincial government the alternative of providing their own police at much greater cost or accepting the limitations on RCMP investigative powers imposed by the Government of Canada.

\section{II}

\section{SPECIFIC Rights}

\section{A. With the Same Meaning as Those Provided by the Bill of Rights}

The Bill of Rights and the Charter provide a broad panoply of rights to persons suspected or accused of a crime. ${ }^{34}$ The Canadian Bill of Rights is clearly the model for the "Legal Rights" section of the Charter. In some instances the language of the Bill is simply incorporated into the Charter. In others a change in language appears to have been adopted for stylistic rather than substantive reasons:

9. Everyone has the right not to be arbitrarily detained or imprisoned ${ }^{35}$

30. See McConnell, supra note 29 , at 189.

31. Constitution Act, 1982, ch. 1, § 24(2); of. Michigan v. DeFillippo, 443 U.S. 31 (1979).

32. See C. GRIffithS, J. KLEIN \& S. Vendin-Jones, supra note 27, at 12-13.

33. See, e.g., Ross v. Registrar of Motor Vehicles, 42 D.L.R.3d 68 (Can. 1974).

34. Constitution Act, 1982, ch. 1, \$§ 7-14.

35. The Bill provides that no law of Canada shall be construed or applied so as "to authorize or effect the arbitrary detention, imprisonment or exile of any person." CAN. BILl OF RighTS, supra note 12, § 2(a). No similar provision was contained in the 1969 PROPOSALS, supra note 22. The 1971 VICTORIA CHARTER, supra note 19, made no provision for Legal Rights. The 1972 Joint Committee adopted the formulation of the 1969 PROPOSALS and hence had no similar provision. 1972 JOINT COMMITTEE REPORT, supra note 19. The 1978 PropOSALS included the right "not to be arbitrarily detained, imprisoned or exiled." 1978 Proposals, supra note 16, § 7. The Canadian Bar Association proposals did not include similar protection. Towards a New Canada, supra note 10. The 1979 Federal Proposals would have been diluted to read "the right against detention or imprisonment except in accordance with prescribed laws and procedures." Gibson, supro note 10, at 372. The 1980 Proposals continued the weakened formulation: "Everyone has the right not to be detained or imprisoned except on grounds, and in accordance with 
10. Everyone has the right on arrest or detention (a) to be informed promptly of the reasons therefor;...

.

(c) to have the validity of the detention determined by way of habeas corpus and to be released if the detention is not lawful. ${ }^{36}$

11. Any person charged with an offence has the right...

(d) to be presumed innocent until proven guilty according to law in a fair and public hearing by an independent and impartial tribunal;

(e) not to be denied reasonable bail without just cause; ${ }^{37}$. . . .

12. Everyone has the right not to be subjected to any cruel and unusual treatment or punishment. ${ }^{38}$

procedures established by law." 1980 Proposals, supra note $19, \S 9$. The provision in this form would have greatly diluted the protection, and objections were voiced by the Premier of New Brunswick, the Canadian Civil Liberties Union, the Canadian Jewish Congress, the United Church, the Canadian Bar Association, and others. The government agreed to the present language reflecting its view that the language means that "the fact procedures are established by law will not be conclusive proof that . . . detention is legal. Such procedures and the laws on which they are based will have to meet the tests of being reasonable and not being arbitrary." 36 JOINT COMMITTEE ProceEdings, supra note 16, at 11 (1981) (statement of Minister of Justice, Mr. Chretien).

36. The Bill of Rights provides that no law of Canada shall be construed or applied so as to

deprive a person who has been arrested or detained (i) of the right to be informed promptly of the reason for his arrest or detention. . . (iii) of the remedy by way of habeas corpus for the determination of the validity of his detention and for his release if the detention is not lawful.

CAN. Bill of Rights, supra note 12, $\S$ 2(c)(i) (iii). Similar language appears in the 1969 Proposals, supra note 22, 2(b), the 1972 JOINT COMMITEE REPORT, supra note 19, the Canadian Bar Association Proposals, Towards a New Canada, supra note 10 , at 19 , and the 1978 Proposals, supra note $16, \S 7$. The language of the 1980 PROPOSALS is identical to that in the 1982 Charter. 1980 PrOpOSALS, supra note $19, \S 10(\mathrm{a}),(\mathrm{c})$.

37. The Bill of Rights provides that no law of Canada shall be construed or applied so as to "deprive a person charged with a criminal offence of the right to be presumed innocent until proved guilty according to law in a fair and public hearing by an independent and impartial tribunal, or of the right to reasonable bail without just cause." CAN. BILL OF RIGHTS, supra note 12, § $2(\mathrm{f})$. The protections were endorsed in the 1969 Proposals, supra note 22, $§ 2(\mathrm{e})$, the 1972 JOINT COMMITTEE REPORT, supra note 19, the Canadian Bar Association Proposals, TOWARdS A New CANADA, supra note 10, at 19, and the 1978 Proposals, supra note $16, \S 7$. The language relating to the presumption of innocence in the 1982 Chapter is identical to that in the 1980 PROPOSALS, supra note $19, \$ 11$ (c). The bail provisions were weaker in the 1980 PROPOSALS: "Anyone charged with an offence has the right (d) not to be denied reasonable bail except on grounds, and in accordance with procedures, established by law." Id. \$11(d). The Government accepted the many objections to the weaker standard and reverted to language reflecting the wording of the Bill of Rights. 36 Joint Committee Proceedings, supra note 16, at 13 (1981).

Mr. Justice McDonald raises the question whether the provision for the presumption of innocence will preclude transferring the burden of proof to a defendant in certain cases; whether the requirement for a "fair hearing" will permit convictions to be set aside on the ground of incompetent counsel; and whether the mandate of a public hearing will preclude closed courts in cases involving juveniles and national security. D. McDonald, Legal Rights in the Canadian Charter of Rights and Freedoms 92, 102, 104 (1982). All three of these grounds have caused substantial litigation in the United States. See Allen \& DeGrazia, The Constitutional Requirement of Proof Beyond Reasonable Doubt in Criminal Cases: A Comment Upon Incipient Chaos in the Lower Courts, 20 AM. CRIM. L. REV. 1 (1982); Bazelon, The Defective Assistance of Counsel, 42 U. CIN. L. REv. 1 (1973); Cox, Foreword: Freedom of Expression in the Burger Court, 94 HARV. L. REV. 1, 19-26 (1980).

38. The Bill of Rights provides that no law of Canada shall be construed or applied so as to "impose or authorize the imposition of cruel and unusual treatment or punishment." CAN. BILL OF Rights, supra note $12, \S 2$ (b). Protection against cruel and unusual punishment was contained in the 1969 PROPOSALS, supra note 22, § 2(h), the 1972 JoINT COMMISsion REPORT, supra note 19, the Canadian Bar Association Proposals, Towards a NeW Canada, supra note 10, at 19, and the 1978 Proposals, supra note $16, \S 7$. The 1979 Federal PROPOSAls recommended "cruel or inhuman" in lieu of "cruel and unusual." See Gibson, supra note 10, at 372. The language of the 1980 ProposALs is identical to that in the 1982 Charter. 1980 Proposals, supra note 19, § 12. The dispute over whether the language should be "and" or "or" apparently reflects the concern of some that, as the section was worded, punishment, no matter how 
14. A party or witness in any proceedings who does not understand or speak the language in which the proceedings are conducted or who is deaf has the right to the assistance of an interpreter. ${ }^{39}$

Similarly, a person accused of crimes in the United States is protected against arbitrary arrest and detention, ${ }^{40}$ has access to habeas corpus to test the legality of a detention, ${ }^{41}$ is presumed to be innocent, ${ }^{42}$ has the right to a public trial by an impartial tribunal, 43 and is protected from the infliction of cruel and inhuman punishment. ${ }^{44}$ The right to be informed promptly of the reason for a detention is not explicitly recognized in the U.S. Constitution but may be protected by the due process clause. ${ }^{45}$ While a defendant is protected against excessive bail by the eighth amendment, ${ }^{46}$ the United States Supreme Court has never held that it applies to the states, ${ }^{47}$ or that the amendment guarantees a right to bail. ${ }^{48}$

The fact that both Canada and the United States recognize a constitutional right does not, of course, suggest that each interprets the dimensions of that right in the same manner. Thus, what constitutes cruel and inhuman punishment in the United States may not necessarily be so regarded in Canada. ${ }^{49}$ In Canada, just cause to detain an arrested defendant pending trial may be predicated upon the need to protect the public from any substantial likelihood that the accused, if released, will commit a criminal offense involving serious harm or an interference

cruel, would be lawful so long as it was not unusual. 22 JOINT CoMmrtTeE Proceedings, supra note 16, at 110 (1980) (testimony of Mr. William Black, British Columbia Civil Liberties Association); see also id., vol. 42 , at $7-8(1981)$.

39. The 1982 Constitution adds protection for the first time to a party or witness who is deaf. The Bill of Rights provided that

no law of Canada shall be construed or applied so as to . . . deprive a person of the right to the assistance of an interpreter in any proceedings in which he is involved or in which he is a party or witness, before a court, commission, board or other tribunal, if he does not understand or speak the language in which such proceedings are conducted.

CAN. Bill of Rights, supra note 12, $\S 2(\mathrm{~g})$. The 1969 Proposals, and subsequent proposals, contained similar protections. 1969 PROPOSALS, supra note 22 , § 2(f); 1972 JOINT COMMISSION REPORT, supra note 19; 1978 Proposals, supro note 16, \& 7; TOWARdS A NEW CANADA, supra note 10, at 19.

40. An illegal arrest violates the fourth amendment. Terry v. Ohio, 392 U.S. 1 (1968); Henry v. United States, 361 U.S. 98 (1959).

41. U.S. CONST. art. I, $\$ 9$, ch. 2.

42. The presumption of innocence is constitutionally protected by the requirement that guilt be established beyond a reasonable doubt. In re Winship, 397 U.S. 358 (1970); see also Kentucky v. Whorton, 441 U.S. 786 (1979); Taylor v. Kentucky, 436 U.S. 478 (1978).

43. U.S. ConST. amend. VI; Ward v. Village of Monroeville, 409 U.S. 57 (1972); In re Oliver, 333 U.S. 257 (1948); Tumey v. Ohio, 273 U.S. 510 (1927).

44. Furman v. Georgia, 408 U.S. 238 (1972); Robinson v. California, 370 U.S. 660 (1962); U.S. CoNST, amend. VIII.

45. U.S. CONST. amends. V, XIV. Modern reformers regard the warning as necessary. See, e.g., A Model Code of Pre-Arraignment Procedure $\$ 130.1$ (2) (1975).

46. U.S. CONST. amend. VIII.

47. U.S. Courts of Appeals have held that the eighth amendment applies to the States. Sistrunk v. Lyons, 646 F.2d 64 (3d Cir. 1981); Hunt v. Roth, 648 F.2d 1148 (8th Cir. 1981), vacated as moot, 455 U.S. $478(1982)$.

48. A recent decision holds that it does not. United States v. Edwards, 430 A.2d 1321 (D.C. 1981) (en banc), cert. denied, 455 U.S. 1022 (1982).

49. Compare Regina v. Miller, 70 D.L.R.3d 324 (Can. 1976), with Furman v. Georgia, 408 U.S. 238 (1972). Whipping was available as a punishment for certain offenses in Canada until 1972. R. SALHANY, Canadian Criminal. Procedure 213 (2d ed. 1972). Such a punishment has been held in the United States to be "cruel and unusual punishment." Jackson v. Bishop, 404 F.2d 571 (8th Cir. 1968). 
with the administration of justice. ${ }^{50}$ Whether detention pending trial can be justified on any basis other than the necessity to ensure the attendance of the defendant at his trial is much more doubtful in the United States. ${ }^{51}$

\section{B. Due Process and Principles of Fundamental Justice}

Some provisions of the Charter have their origin in the Bill of Rights, but are expressed in language that suggests an intent to modify the substance of the right protected. Thus the Charter provides that: "Everyone has the right to life, liberty, and security of the person and the right not to be deprived thereof except in accordance with the principles of fundamental justice." 52 In comparison, the Bill of Rights asserted the existence of "the right of the individual to life, liberty, security of the person and enjoyment of property, and the right not to be deprived thereof except by due process of law." 53

The protection of property has been deleted from the guarantee of the Charter, and "principles of fundamental justice" has replaced "due process of law" as the criterion for justifying deprivation. ${ }^{54}$ The phrase "principles of fundamental jus-

50. R. SAlHaNY, supra note 49 , at 63 .

51. See Stack v. Boyle, 342 U.S. 1 (1951); United States v. Edwards, 430 A.2d 1321 (D.C. 1981) (en banc), cert. denied, 455 U.S. 1022 (1982).

52. Constitution Act, 1982, ch. 1, § 7.

53. CAN. BiLl of Rights, supra note $12, \S 1$ (a).

54. The constitutional protection of property rights was severed from the rights to life and liberty and security of the person in the 1969 Proposals. Those proposals would have assured life, liberty, and security of the person against deprivation "except by due process of law;" an individual could not be denied the right to the enjoyment of property "except according to law." 1969 PropOSALS, supra note 22, $\S 1(\mathrm{e})(\mathrm{f})$ at 52 . The distinction was intended to indicate "that what should be required for the protection of property is procedural fairness, whereas 'due process' might be capable of a broader meaning which could unduly limit legislative action." Id. at 52 . No similar provision was included in the 1971 VICTORIA CHARTER, supra note 19. The language of the 1972 JOINT COMMITTEE REPORT is identical to that of the 1982 Charter. 1972 JoINT CommitTeE RePORT, supra note 19, at 19. The Parliamentary Committee explained its choice of language:

We should like to avoid the use of the phrase "due process of law" entirely, because it is a phrase which has no tradition in our law, despite its incorporation in the 1960 Bill of Rights, and because of its unfortunate interpretation in the United States under substantive due process. At its worst this phrase gave judges leeway to substitute their socio-economic views for those of legislatures. In our view it is more desirable to use another phrase found in the Canadian Bill of Rights, "the principles of fundamental justice."

Id. It should be noted that the phrase "the principles of fundamental justice" is used only in an oblique fashion in the Bill of Rights provision that no law shall be construed or applied so as to "deprive a person of the right to a fair hearing in accordance with the principles of fundamental justice . . . ." CAN. BILL OF Rights, supra note $12, \S 2($ e). The Parliamentary Committee in 1972 also proposed a separate provision to protect property rights: "The right of the individual person to the enjoyment of property, and the right not to be deprived thereof except in accordance with the public good and for just compensation." 1972 JOINT COMMTTEE REPORT, supra note 19 , at 20.

The Canadian Bar Association Proposals approved the formula of the 1969 Proposals, rejecting the 1972 proposal for explicit constitutional protection for property rights on the grounds that "the question whether the taking of property is for the public good is clearly one for the legislatures" and that "economic rights are not appropriate for protection in a Bill of Rights." TOWARDS A NEW CANADA, supra note 10, at 18-19. The 1978 Proposals returned to the language of the 1969 Proposals. 1978 Proposals, supra note 16 , at $\S 6$. The 1979 Federal Proposals recommended that the right to use and enjoy property be extended to groups as well as individuals and provided that the right to enjoy property is subject to deprivation only "in accordance with law that is fair and just," while calling for specific provision for the right of legislatures to make laws "which control or restrict use of property in public interest." Gibson, supra note 10, at 368-69. The language of the 1980 Proposals is identical to that of the 1982 Charter, the explana- 
tice" is not defined in the constitution. Perhaps this phrase was used instead of the phrase "due process" in order to forestall the possibility of entrenching in Canadian jurisprudence a concept of "substantive due process," as exemplifed by the United States Supreme Court cases dealing with economic regulation in the 1930's. If so, the choice of language seems questionable. ${ }^{55}$ The separation of property rights from personal rights would have been adequate protection against resurrection of an American doctrine which has been largely quiescent for almost half a century. Indeed, with the exception of a few areas, it is difficult to find examples in recent American history of the use of "substantive due process" in matters affecting life and liberty. ${ }^{56}$

The use of the phrase "principles of fundamental justice" may reflect concern that courts might hold that any procedure permitted by the law constitutes "due

tory notes indicating that the provision is derived from $\S 1$ of the Canadian Bill of Rights. 1980 PROPOSALS, supra note 19, at 16 . No explicit provision for the protection of property is included in the 1982 Constitution, allegedly out of respect for the provincial property and civil rights jurisdiction under $\$ 92(13)$ of the BNA. Laskin, supra note 19 , at 343 n. 12 .

The Joint Parliamentary Committee considered a number of phrases: "due process of law," 21 JOINT Committee Proceedings, supra note 16, at 21 (1980); "principles of natural justice," id., vol. 41, at 98 (1981); and "principles of fundamental justice, including the principles of due process of law," id., vol. 46, at 30-45. Views were expressed that "principles of fundamental justice" was a "more encompassing" phrase than "due process," id., vol. 2, at 21 (1980) (statement of Mr. Edwin Webking, Canadian Federation of Civil Liberties and Human Rights Associations); that "fundamental principles of justice" might be "more restrictive," id., vol. 46, at 35 (1981) (statement of Mr. John Fraser); that "due process" would not only include the concepts of procedural fairness covered by "principles of fundamental justice," but also might include "substantive fairness" permitting the courts to second guess Parliament or legislatures on the policy of law, id. at 36 (statement of Dr. B.L. Strayer); that "principles of natural justice" has been limited to the right to an impartial tribunal and a right to be heard, while "principles of fundamental justice" leaves the opportunity for courts to move into new fields of jurisprudence, id. at 36 ; id., vol. 44 , at 19 (statements of Mr. Robinson); and that the terms "fundamental justice" and "natural justice" are essentially the same, each referring to procedural fairness, id., vol. 46 , at 38 (statement of Dr. B.L. Strayer). The Minister of Justice tersely stated the government's objection to including "due process" as the standard: "In simple terms, you are giving more power to the courts over the substance of the legislation that a different legislature will pass in Canada." Id. at 41 (statement of Mr. Chrétien).

It has been argued alternatively that the section includes the other enumerated rights in addition to broader protection and may be "one and the same" as due process. D. MCDONALD, supra note 37, at 20, 23.

55. See Laskin, supra note 19 , at 343.

56. The decision declaring certain abortion laws to be unconstitutional is an example. Roe v. Wade, 410 U.S. 113 (1973); see also Loving v. Virginia, 388 U.S. 1, 12 (1967); Kent v. Dulles, 357 U.S. 116 (1958); but see Morgentaler v. The Queen, 53 D.L.R.3d 161 (Can. 1975) (rejecting challenge to abortion law). It seems more likely that the intent of the government was to limit the powers of courts to invalidate legislation dealing with life and personal liberty. The examples used by the Minister of Justice in opposing "due process" as a standard were capital punishment and abortion:

The point, Mr. Crombie, that it is important to understand the difference is that we pass legislation here on abortion, criminal code, and we pass legislation on capital punishment; Parliament has the authority to do that, and the court at this moment, because we do not have the due process of law written there, cannot go and see whether we made the right decision or the wrong decision in Parliament.

If you write down the words, "due process of law" here, the advice I am receiving is the court could go behind our decision and say that their decision on abortion was not the right one, their decision on capital punishment was not the right one, and it is a danger, according to legal advice I am receiving, that it will very much limit the scope of the power of legislation by the Parliament and we do not want that; and it is why we do not want the words "due process of law". These are the two main examples that we should keep in mind.

46 Joint Committee Proceedings, supra note 16, at 43 (1981) (statement of Mr. Chrétien). 
process of law." 57 The concern that "procedural due process" might become a residuary source of judicial power to expand procedural rights of an accused beyond those originally intended by the constitution, as has arguably been the case in the United States, ${ }^{58}$ has some justification; yet it is difficult to see how the phrase "principles of fundamental justice" provides less opportunity for expansion to a court so inclined. Arguably, if the phrase "due process of law" were used, Canadian justices might be unduly influenced by the interpretation of similar language by their American cousins, a proposition not sustained by their past behavior. ${ }^{59}$

\section{Custodial Interrogation, Right to Counsel, and Self-Incrimination}

1. Custodial Interrogation. The Canadian Bill of Rights provided that no law shall be construed or applied "so as to . . . deprive a person who has been arrested or detained . . . of the right to retain and instruct counsel without delay."60 Section 10 of the Charter incorporates this protection but goes further and assures that an arrestee or detainee is informed of that right. ${ }^{61}$ The right to counsel is obviously of little significance to an accused who is ignorant of the existence of such a right, and there is reason to believe that a high percentage of arrested persons are unaware that they have the right to retain counsel at this stage of a police investigation. ${ }^{62}$

The combination of the right to retain and instruct counsel with assurance that an accused will know he has such a right, the right to be informed promptly of the reasons for the arrest, and the right to test the legality of a detention, provides theoretically significant protections to an accused who has been taken into police custody. Whether they provide realistic protection to suspects who are most in need of counsel is more doubtful.

57. Brandt, supra note 12, at 284; Gibson, supra note 10 , at 372 .

58. The application of provisions of the U.S. Bill of Rights to the states by "incorporation" into the due process clause of the fourteenth amendment, perhaps the most far reaching "extension" of due process by the Supreme Court of the United States, would not appear to be a problem because the provisions of the 1982 Canadian Constitution apply to the provinces directly. Other themes in the American precedents, such as equality of treatment for the rich and the poor, reflected in the overtones of cases such as the right to counsel cases, e.g., Gideon v. Wainwright, 372 U.S. 335 (1963); the willingness to ignore the long history of a practice when "changed circumstances suggest the wisdom of a different result," e.g., Taylor v. Louisiana, 419 U.S. 522, 537 (1975); the occasional propensity to use a particular case to legislate a code of permissible practices, e.g., North Carolina v. Pearce, 395 U.S. 711 (1969); and the cases that used the due process clause to create a constitutional standard of "voluntariness" governing the admission of confessions, e.g., Haynes v. Washington, 373 U.S. 503 (1963), Rogers v. Richmond, 365 U.S. 534 (1961), may provide greater causes for concern.

59. Thus far there is little evidence of such an abdication of independent judgment. Tamopolsky Lecture, supra note 10, at 177-81; see also Regina v. Miller, 70 D.L.R.3d 324 (Can. 1976); Smythe v. The Queen, 1971 S.C.R. 680 (Can.). One wonders if the Supreme Court of Canada would tolerate the use of a stomach pump as in Rochin v. California, 342 U.S. 165 (1952).

60. CAN. Bill of Rights, supra note $12, \S 2$ (c)(ii).

61. Constitution Act, 1982, ch. $1, \S 10(\mathrm{~b})$. The right does not appear in the earlier proposals. The Supreme Court had stated that the police had no obligation to advise an accused of his rights. Brownridge v. The Queen, 28 D.L.R.3d 1 (Can. 1972). The government added the phrase at the suggestion of several witnesses. JoINT Committee Proceedings, supra note 16, at 12 (1981).

62. See Comment, Due Process Safeguards and Canadian Criminal Justice-A Reply to a Critique, 14 CRIM. L.Q. 276 (1972) (discussing Canadian Civil Liberties Education Trust, Due Process Safeguards and Canadian Criminal Justice (1972)). 
The period between arrest and presentment before the magistrate may give rise to several quite different situations: (1) a simple detention following arrest, during which no significant interaction occurs between the police and the accused; (2) a detention accompanied by police efforts to persuade the accused to cooperate with investigative efforts by measures short of interrogation, such as participating in a lineup or submitting to a breathalyzer; or (3) detention accompanied by efforts by interrogators to obtain incriminating statements from the arrestee. This period of time is frequently characterized by police conduct of the kind described in (2) and (3). It is a fair inference that an arrestee who is informed of his right to counsel and has retained counsel usually has reasonable protection in both (2) and (3). The same results may be true if the legal aid scheme of a province provides counsel for an indigent at the detention facility, or if the accused or his family is otherwise able to acquire the services of such counsel. Quite a different result may occur, however, when the person detained has no access to a lawyer. A suspect who does not know how to retain an attorney or who is unable to afford one and who is arrested in a place where Legal Aid Duty Counsel is unavailable may find that the constitutional right of counsel is illusory. The level of protection in such cases falls far short of the protection afforded a person subjected to a custodial police interrogation in the United States, if the suspect asserts his desire to consult counsel, no counsel is provided him, and a statement is elicited from him. ${ }^{63}$

The Charter does not expressly grant to an accused the right to remain silent, and, hence, he is not entitled to a warning that he possesses such a right. For the same reason, the Canadian arrestee is not entitled to a warning that anything said may be used against him in court, nor, apparently, is there any requirement that an interrogation must cease if the defendant indicates that he wishes to remain silent.

While he must be informed of his right "to retain and instruct counsel," it is not clear that the Canadian suspect must be told that he has the right to have the lawyer with him during his interrogation. Arguably, "the assertion by a defendant of his desire to consult an attorney without delay" would require that the interrogation cease until an attorney is present, ${ }^{64}$ as is required in the United States. $\mathrm{He}$ is not entitled to be informed that he has a right to have a lawyer appointed for him if he is unable to afford one because he has no such constitutional right.

2. Right to Counsel. The difference in approach stems from the narrower concepts of "right to counsel" and "self-incrimination" reflected in the Charter. The

63. See Edwards v. Arizona, 451 U.S. 477 (1981). The rights of a defendant in a custodial interrogation in the United States are set forth in Miranda v. Arizona, 384 U.S. 436 (1966). The procedural safeguards, while not themselves constitutional rights, are "measures to insure that the right against compulsory self-incrimination was protected." Michigan v. Tucker, 417 U.S. 433, 444 (1974). A number of witnesses urged that provision be made to supply counsel to an accused unable to afford a lawyer. See, e.g., 37 Joint Committee Proceedings, supra note 16, at 24 (1981); id, vol. 29, at 26 (1980); id., vol. 24, at 44; id., vol. $26 \mathrm{~A}$, at 3 . Efforts to include such a proposal failed. Id., vol. 46, at 127-35 (1981). The government resisted such incorporation on the grounds that legal aid was presently a part of the legal system, was unlikely to be repealed, and ilat all rights could not be placed in the Constitution. Id., vol. 36, at 25-26 (1981); id., vol. 46, at 131 (statements of Mr. Chrétien, Minister of Justice).

64. It can cogently be argued that Hogan v. The Queen, 48 D.L.R.3d 427 (Can. 1974), requires such a result. 
"right to counsel" provision is limited to the right to "retain and instruct" and does not require that counsel be appointed for an accused unable to afford one at trial, much less at a police interrogation. The 1972 Parliamentary Committee expressly rejected the wisdom of including a provision in the constitution assuring counsel to those unable to afford a lawyer on the understandable basis that the provinces were not yet willing to pay for the implementation of such a proposal, and on the less understandable ground that providing positive benefits are appropriately the subject of nonconstitutional legislation and not that of charters, which should have a primarily negative thrust. ${ }^{65}$ The crucial significance of appointing counsel for a defendant to protect against the excesses of government power and the inherent unfairness of any contest in which only one side has a goalie was apparently as unpersuasive in 1981 as it had been in 1972 .

Obviously, provisions for legal aid made by the provinces may greatly ameliorate the practical impact of the omission from the constitutional scheme of provision for counsel for the indigent. It is nevertheless surprising that more concern has not been expressed over the failure to provide such a right in the constitution. It seems unlikely that the "fair hearing" provision ${ }^{66}$ will be interpreted to require the appointment of counsel for an indigent, ${ }^{67}$ and arguments predicated upon the "equal protection clause" are not likely to be persuasive. ${ }^{68}$

65. Just as important as these guarantees of fair legal process is the provision of legal advice and legal counsel to those who cannot otherwise afford them. Although there has been a growing awareness across the country of the acute need in this field, the majority of the Provinces still do not have publicly supported programs of legal aid which are generally available. It is our hope that the initiative which the Federal Government has recently taken in establishing a legal aid program in the Northwest Territories will be followed elsewhere and expanded everywhere. We would particularly stress that the disadvantaged in our society need counselling as well as counsel, and that an adequate program of legal assistance will ensure that this need is met, through the development of direct governmental services, if necessary. Nevertheless, since the provision of adequate legal service necessitates the development of a considerable program of implementation, we cannot recommend it for inclusion in a Bill of Rights: for a constitutional charter of liberties most needs have a primarily negative thrust, by way of protecting people against an excess of governmental power. The providing of positive benefits is rather the stuff of ordinary legislation.

1972 JoINT COMmitee RePORT, supra note 19, at 20-21.

66. Constitution Act, 1982, ch. 1, §11(d) ("Any person charged with an offence has the right ... (d) to be presumed innocent until proven guilty according to law in a fair and public hearing ....."). Arguably, the protection is less clear than the provision of the Canadian Bill of Rights from which it was apparently derived. Section 2(e) of the Bill of Rights provided that no law should be so construed or applied so as to "deprive a person of the right to a fair hearing in accordance with the principles of fundamental justice for the determination of his rights and obligations." CAN. BILL OF RigHTS, supra note 12. The language of the Bill of Rights was copied in the 1969 Proposals, supra note 22, $\S 2$ (e), the 1972 JoInt Committee Report, supra note 19, the Canadian Bar Association Proposals, Towards A New CANADA, supra note 10 , at 19 , and the 1978 PropOSALS, supra note $16, \S 7$. The language of the 1982 Canadian Constitution first appeared in the 1980 Proposals, with the explanatory note that it would "assure rights of accused in criminal and penal proceedings" at present found in paragraphs 2(e) and 2(f) of the Bill of Rights. 1980 Proposals, supra note 19 , at 18.

67. See the arguments advanced in Black, Right to Counsel at Trial, 53 CaN. B. REv. 56 (1975).

68. Constitution Act, 1982, ch. $1, \S 15(1)$ provides that "[e]very individual is equal before and under the law and has the right to the equal protection and benefit of the law without discrimination and, in particular, without discrimination based on race, national or ethnic origin, colour, religion, sex, age or mental or physical disability." The provision is not included in the "Legal Rights" sections of the Charter, but might in appropriate cases have significance in criminal litigation, such as cases in which discriminatory enforcement of laws can be established. Cf. Oyler v. Boles, 368 U.S. 448 (1962) (reasonable selectivity in enforcing habitual criminal statute no violation of equal protection, if not based on arbitrary classification); Butler v. Cooper, 554 F.2d 645 (4th Cir. 1977) (allegations of racially selective enforcement of liquor laws not proven); United States v. Falk, 479 F.2d 616 (7th Cir. 1973) (en banc) (selectivity in enforcing law 
3. Self-Incrimination. Protection against self-incrimination is found in two sections of the Charter: section 11(c) provides that any person charged with an offense has the right "not to be compelled to be a witness in proceedings against that person in respect of that offence." 69 Additional protection is afforded by section 13 , which states that a witness who testifies in any proceeding has the right "not to have any incriminating evidence so given used to incriminate that witness in any other proceedings, except in a prosecution for perjury or for the giving of contradictory evidence."70 Each is different from the provision in the Bill of Rights that no law shall be construed or applied so as to "authorize a court, tribunal, commission, board or other authority to compel a person to give evidence if he is denied counsel, protection against self crimination or other constitutional safeguards."71

An accused is protected in two different ways by the constitutional provisions. He cannot be compelled to be a witness against himself in "proceedings against that person in respect of that offence." 72 Furthermore, if he does testify in such a

requiring possession of draft registration card may violate equal protection if based on conduct protected by first amendment). The history of the provision does not suggest that the purpose of the provision was to deal with the problem of low visibility disparities that exist between the rich and the poor in the criminal process. Cf. Mayer v. City of Chicago, 404 U.S. 189 (1971); Douglas v. California, 372 U.S. 353 (1963); Griffin v. Illinois, 351 U.S. 12 (1956).

69. Constitution Act, 1982, ch. $1, \S 11(\mathrm{c})$.

70. Id. $\$ 13$.

71. CaN. Bill of Rights, supra note 12, §2(d). The 1969 Proposals recognized "the right of a person not to give evidence before any court, tribunal, commission, board or other authority if he is denied counsel, protection against self-crimination, or other constitutional safeguards." 1969 PROPOSALS, supra note 22, $\S 2$ (c). The 1972 JOINT COMMITTEe RePORT, supra note 19, the Canadian Bar Association Report, Towards a NEw CANAdA, supra note 10, at 19, and the 1978 Proposals, supra note 16 , $\$ 7$, contained the same provision. The 1979 Federal Proposals limited the right not to testify to circumstances when the individual was "compelled to testify." Gibson, supra note 10, at 372 . The limitation was continued in the 1980 Proposals: "A witness has the right when compelled to testify not to have any incriminating evidence so given used to incriminate him or her in any other proceedings, except a prosecution for perjury or for the giving of contradictory evidence." 1980 Proposals, supra note 19, $\$ 13$. The explanatory note indicated that the provision was an "elaboration of the right now provided in paragraph 2(d) by the Bill of Rights." Id. at 18. Section 13 of the 1982 Canadian Constitution tracks the 1980 PROPOSALS except that it does not require that the testimony has been compelled. The Minister of Justice explained the reasons for the change in $\$ 13$ :

Section 13 of the proposed Charter as drafted does not protect an accused or other witness who voluntarily gives evidence from having the evidence so given used to incriminate him in subsequent proceedings.

I would propose an amendment to ensure that this clearly recognized principle in the law of evidence be reflected in the constitutional protection against self-crimination.

36 Joint Committee Proceedings, supra note 16, at 13 (1981) (statement of Mr. Chrétien).

Section 11 (c) appears for the first time in the constitution. It was added in the Joint Committee on the motion of Mr. Irwin. Id., vol. 47, at 43-44. The limited nature of the protection was made clear by the explanation provided by the Director of the Criminal Law Amendments Section of the Department of Justice, Mr. Ewaschuk: "What this means is only when he is being tried does he have the right not to testify against himself. So that is only when his liberty is at stake during that trial." Id. at 44.

72. The protection given to an accused not to testify is thus put on a constitutional footing, where previously it rested upon the common law principle that an accused was not compellable, a principle that was not changed when an accused was made competent to testify. See E. RatushNY, SELF-INCRIMINATION IN THe Canadian Criminal Process 67 (1979). It will be interesting to see whether the new constitutional status of "noncompellability" will put some teeth in the prohibition against commenting on the failure of a defendant to testify:

It has been demonstrated that the rule in Section 4(5) of the Canadian Evidence Act, forbidding comment upon a failure to testify, has been greatly restricted in scope. It is operative only in jury 
proceeding, or in any other proceeding, and provides evidence which proves incriminating, it may not be used against him except in a subsequent prosecution for lying.

In comparison, an individual in the United States cannot be called as a witness in a case where he is accused of a crime, and if he is called in a case in which he is not charged, civil or criminal, he can refuse to answer any questions that tend to incriminate him, ${ }^{73}$ unless he is granted immunity from the subsequent use of that evidence against him. ${ }^{74} \mathrm{~A}$ Canadian accused of a crime can be required in a civil proceeding to answer a question that tends to incriminate him. ${ }^{75}$ If he is charged separately from other parties, he can be compelled to testify about the offense with which he is charged if called as a witness at their trial. ${ }^{76}$ An individual already charged with a crime may be compelled to testify in an investigatory proceeding, the object of which is to explore the matter that gave rise to his prosecution. ${ }^{77}$

The Canadian accused who answers self-incriminating questions, even if he is not compelled so to testify, is apparently protected, however, against the use of such statements against him in a subsequent proceeding. ${ }^{78}$ The language of the Charter would seem to indicate that if $A$ is charged with a crime and $B$ testifies on $A$ 's behalf and in so doing $B$ incriminates himself, the government is precluded from using those admissions in a subsequent trial of $B .{ }^{79}$ In substance, the witness is given a limited form of "use" immunity whenever he testifies. Section 13 of the Charter does not expressly require that a witness be called by the prosecution or

trials. Moreover, it is clearly permissible in law for the trier of fact, including a jury, to draw adverse inferences against an accused because of his failure to testify.

Id. at 331. Compare Avon v. The Queen, 21 D.L.R.3d 442 (1972) (instructions by the court "stating" but not "commenting" upon the accused's failure to testify did not amount to reversible substantial wrong or miscarriage of justice), with Griffin v. California, 380 U.S. 609 (1965) (the fifth amendment privilege against self-incrimination forbids comment by prosecution on accused's silence and instructions by the court that such silence is evidence of guilt).

73. Lefkowitz v. Turkey, 414 U.S. 70 (1973).

74. Kastigar v. United States, 406 U.S. 441 (1972).

75. Canada Evidence Act, Can. Rev. Stat. ch. E-10, § 5(1) (1970).

76. In re Ragan, [1939] 2 D.L.R. 135 (Can.).

77. See Regina v. Quebec Mun. Comm'n, 11 D.L.R.3d 491 (Can. 1969). The Canadian Supreme Court has precluded calling a person to testify at a coroner's inquest when he already has been charged with murder. Batary v. Attorney Gen., 52 D.L.R.2d 125 (Can. 1965). But see Faber v. The Queen, 65 D.L.R.3d 423 (Can. 1975).

78. The language of the Canadian Constitution is much broader than the existing statutory language which reads as follows:

Where with respect to any question a witness objects to answer upon the ground that his answer may tend to criminate him, or may tend to establish his liability to a civil proceeding at the instance of the Crown or of any person, and if but for this Act, or the Act of any provincial legislature, the witness would therefore have been excused from answering such question, then although the witness is by reason of this Act, or by reason of such provincial Act, compelled to answer, the answer so given shall not be used or receivable in evidence against him in any criminal trial, or other criminal proceeding against him thereafter taking place, other than a prosecution for perjury in the giving of such evidence.

Canada Evidence Act, CaN. REv. Stat. ch. E-10, § 5(2) (1970). The existing law requires the witness to claim the privilege if he wishes to preclude the use of his testimony against him in the future. Tass $v$. The King, [1947] 1 D.L.R. 497 (Can.).

79. It is, of course, possible that the constitutional protection may be limited to the existing statutory protection despite the breadth of the language. Such a holding would require some judicial ingenuity in view of the change of language between the 1980 Proposals and the 1982 Canadian Constitution, see supra note 71 , and the statement of the Minister of Justice, supra note 71. 
that he assert the privilege when called. ${ }^{80}$

The prohibition against use of prior testimony of a witness to incriminate him in other proceedings does not go so far as to provide "transactional" immunity to that witness. ${ }^{81}$ Nor does the prohibition go so far as to prohibit the use of "derivative evidence," obtained as a result of testimony of a witness ${ }^{82}$ even if the testimony is compelled. An American defendant, on the other hand, is entitled to protection from the use of "derivative evidence" as the price for his compelled testimony. ${ }^{83}$

It is not clear why a privilege against self-incrimination should protect persons who voluntarily incriminate themselves. The spectacle of $A$ obtaining an acquittal as a result of $B$ 's admission of guilt, and $B$ then obtaining an acquittal on the basis of $A$ 's judicial confession of guilt, when his previous statement is inadmissible, will do little to raise public confidence in the criminal justice system. It is also not clear why a person should not be protected from any use of his testimony, including the use of evidence obtained as a result of it, if his testimony is compelled when he otherwise would have chosen to remain silent.

While providing for a privilege against self-incrimination, sections 11 (c) and 13 both limit their applicability to statements made in "proceedings." There is nothing that suggests any intention to extend the protection against self-incrimination to a person arrested or detained but not yet charged with an offense, or to test the admissibility of a pretrial statement to the police by any standard other than voluntariness. ${ }^{84}$

\section{Other Protections for Persons Charged with Offenses}

The Charter contains several other provisions of importance to persons charged with an offense that were not included in the Bill of Rights. Sections 11 (a) and 11 (b) guarantee an accused the right "to be informed without unreasonable delay of the specific offence" and "to be tried within a reasonable time." 85 The meaning

80. "The Fifth Amendment does not protect an individual from every incriminating statement he might make. Barring all self-incriminating admissions from introduction at trial would immeasurably hinder the administration of criminal justice." C. Whitebread, Criminal Procedure 264 (1980); see also United States v. Washington, 431 U.S. 181, 187 (1977).

81. "Transactional immunity" refers to a grant by the state of immunity from prosecution for the transaction to which the compelled testimony relates as distinguished from "use immunity" which only prohibits the use of the incriminating statements themselves, and evidence derived therefrom, in a future prosecution. Cf. C. LILly, AN INTRODuction to THE LAW OF EVIDENCE 341-42 (1978).

The American Constitution is satisfied if use immunity is given in exchange for the compelled testimony. Kastigar v. United States, 406 U.S. 442 (1972).

82. Thus, the QUIMET REPORT comments: "A searching examination may . . . elicit facts or clues which enable the case to be independently proved." REPORT OF THE CANADIAN COMMTTTEE ON CORRECTIONS 68 (1969).

83. See Kastigar v. United States, 406 U.S. 441 (1972).

84. In Curr v. The Queen, 26 D.L.R.3d 603 (Can. 1972), § 2(d) of the Bill of Rights was interpreted to limit the privilege against self-incrimination to testimony before a court or like tribunal. See Rothman v. The Queen, 35 N.R. 485 (Can. 1981); see generally F. Kaufman, The Admissibility of Confessions (1979); E. RATUShNY, supra note 72, at 65; Schrager, Recent Developments in the Law Relating to Confessions: England, Canada and Australia, 26 MCGiLL L.J. 435, 503-05 (1981). A proposal to assure that any person charged with an offense would be entitled to protection against self-incrimination from the moment of arrest and the right to be informed of that right was defeated. 47 JOINT COMMTTTEE PROCEEDINGS, supra note 16 , at 28 .

85. These rights were included in the 1979 Federal Proposals, Gibson, supra note 10, at 372 , and 
of the "speedy trial" provision is unclear, but it seems reasonable to infer that it is concerned with delay between charge and trial, and not with delay between commission or arrest and charge. ${ }^{86}$

Under Canadian law, a right to trial by jury in serious cases is assured by a constitutional provision granting the right to trial by jury where the maximum punishment for the offense is imprisonment for five years or more, except in cases coming under military law. ${ }^{87}$ Presumably, a defendant will still be permitted to elect trial by the court where permitted to do so by statute. ${ }^{88}$ It is unclear whether the jury must be composed of twelve persons. ${ }^{89}$ There is no reason to infer that a less than unanimous verdict would suffice under the provision. ${ }^{90}$ In the United States, on the other hand, a defendant in a civilian court has a right to jury trial in all criminal prosecutions ${ }^{91}$ except those for "petty offenses,"92 but neither a jury of twelve $^{93}$ nor a unanimous verdict ${ }^{94}$ is required. A person may not be tried within the United States by court-martial for a "civilian type" offense. 95

In a sense the most extraordinary provision of the Charter is the provision prohibiting ex post facto laws:

were contained in the 1980 PROPOSALS, which indicated that they were derived from similar provisions in the U.N. Covenant. 1980 Proposals, supra note 19, at 18. There was extensive discussion of the use of "without unreasonable delay" instead of "promptly" in $\S 11(\mathrm{a})$, with the former preferred because of the greater flexibility implicit in the language. 47 JoINT CoMmitTeE Proceedings, supra note 16, at 32-43. It has been suggested that the provision may give rise to the development of the concept of abuse of process. D. MCDONALD, supra note 37 , at 88 .

86. The American cases have so interpreted the provision of the sixth amendment guaranteeing that "the accused shall enjoy the right to a speedy . . . trial." U.S. CoNST. amend VI (emphasis added); see also United States v. MacDonald, 456 U.S. 1 (1982); United States v. Marion, 404 U.S. 307 (1971). But see United States v. Lovasco, 431 U.S. 783 (1977) (due process has limited role to play in protecting against preindictment delay). The American test balances a number of factors in determining if the defendant's right has been violated, including the length of the delay, the claimed justification, the prejudice caused to the defendant, and whether the defendant sought earlier trial. Barker v. Wingo, 407 U.S. 514 (1972).

87. Constitution Act, 1982, ch. 1, $\S 11(\mathrm{f})$ : "Any person charged with an offence has the right ... (f) except in the case of an offence under military law tried before a military tribunal, to the benefit of trial by jury where the maximum punishment for the offence is imprisonment for five years or a more severe punishment." The provision does not appear in earlier proposals. The absence of a provision for trial by jury was criticized by witnesses, 21 JoINT CoMmitTee Proceedings, supra note 16, at 8 (1980), and a proposal for trial by jury in all cases where the punishment imposable was two years or more was made by the New Democratic party. Id., vol. 42 , at $7(1981)$, id., vol. 47 at 54 . The government proposed the provision, stressing that it was a minimal provision and that the Criminal Code would continue to provide jury trials in many cases where the maximum punishment is less than five years. Id., vol. 36, at 12.

88. When the offense charged is punishable by less than five years in prison, the Attorney-General may require under existing law that the accused be tried by a court composed of judge and jury. Criminal Code, Can. Rev. Stat. ch. C-34, $\$ 498$ (1970).

89. At present in the Yukon and Northwest Territories, six persons instead of twelve may be sworn as a jury to try an indictment. R. SALHANY, supra note 49 , at 145 n.40. A trial may continue with consent of the parties following the death or discharge of a juror if the number of jurors is not reduced below ten (five in the Yukon and Northwest Territories). Id. at 152-53.

90. Cf. R. SalhaNY, supra note 49, at 167: "From the earliest times, the criminal law of England has recognized that the verdict of the jury must be unanimous either for conviction or acquittal of the accused."

91. U.S. Const. amend. VI.

92. Baldwin v. New York, 399 U.S. 66 (1970); District of Columbia v. Clawans, 300 U.S. 617 (1937).

93. Williams v. Florida, 399 U.S. 78 (1970); of. Ballew v. Georgia, 435 U.S. 223 (1978) (five persons are too few).

94. Apodaca v. Oregon, 406 U.S. 404 (1972). But see Burch v. Louisiana, 441 U.S. 130 (1979) (5-1 vote not sufficient).

95. O'Callahan v. Parker, 395 U.S. 258 (1969). 
11. Any person charged with an offence has the right . . .

(g) not to be found guilty on account of any act or omission unless, at the time of the act or omission, it constituted an offence under Canadian or international law or was criminal according to the general principles of law recognized by the community of nations;

(i) if found guilty of the offence and if the punishment for the offence has been varied between the time of commission and the time of sentencing, to the benefit of the lesser punishment. ${ }^{96}$

The presence of an ex post facto provision is less extraordinary than would be its absence in a charter of rights. ${ }^{97}$ What is remarkable is the use of "international law" and the "general principles of law recognized by the community of nations" in addition to domestic law as the base point from which the lawfulness of retroactive legislation will be judged. The scope of what constitutes an offense under international law, much less what is criminal according to the general principles of law recognized by the community of nations, is less than clear. Even if certain conduct clearly constitutes an offense against such "law" or "principles," it is less than clear that a national sovereign should be authorized to retroactively make such conduct an offense against its domestic laws. ${ }^{98}$ The Canadian Parliament clearly has the power to punish acts done outside Canada, at least acts committed by its own citizens, and the Parliament has exercised that power in punishing conduct such as the hijacking of an aircraft. 99 In the future, it could presumably enact a law creating an offense such as "torture" and apply it retroactively to the conduct of its citizens abroad if "torture" is found to be either an offense against international law or criminal conduct according to the principles of law recognized by the community of nations. ${ }^{100}$ Thoughtful observers may differ as to the

96. Constitution Act, 1982, ch. 1, $\$ 11(\mathrm{~g})$ (i). The 1969 Proposals recommended protection of the right of a person not to be held guilty of an offence on account of any act or omission which at the time of its commission or omission did not constitute an offence, and the right of a person on being found guilty of an offence not to be subjected to a penalty heavier than the one applicable at the time the offence was committed.

1969 Proposals, supra note 22, $\S 2(\mathrm{~g})$, at 54. The 1972 JoInt Commission RePORT, supra note 19, the Canadian Bar Association Proposals, TOWAR dS A New CANADA, supra note 10, at 19, the 1978 PropOSALS, supra note 16, $\S 7$, the 1979 Federal Proposals, Gibson, supra note 10, and the 1980 PropOSALS, supra note $19, \S 11(\mathrm{e}),(\mathrm{g})$ recommend the same or similar language.

97. Limitations upon the power to enact retrospective legislation are a part of the U.S. Constitution. U.S. CoNST. art. I, $\S 9, \mathrm{cl} .3, \S 10$, cl. 1 .

98. Incorporation of the standard referring to international law resulted from concerns voiced by the Canadian Jewish Congress, the North American Jewish Students Association, and others that the ex post facto provisions not preclude the possibility of prosecuting persons alleged to have committed crimes recognized under international law. The International Covenant on Civil and Political Rights recognizes the right of a country to prosecute a person for an offense that was, at the time of the commission, a crime under international law even if not so recognized under domestic law. The provision reflects such an approach. 36 JoINT CommitTé Proceedings, supra note 16, at 12-13. The language "general principles of law recognized by civilized nations" apparently refers to the general principles of law common to the major legal systems of the world. Recent commentators have argued that whether a general principle is appropriate for absorption by international law will change with the development of international law, suggesting that it is now plausible to consider whether a rule against torture is part of international law, derived from the fact that such a principle is common to all major legal systems. RESTATEMENT OF FOReign Relations LaW of the United States $\$ 102$, reporter's note 7 (Tent. Draft No. 1, 1980). Assuming that a rule against torture is common to all major legal systems, it is unclear to the author what the common penalty is supposed to be.

99. Criminal Code, Can. Rev. Stat. ch. C-34, \$§ 6, 46 (1970); P. HoGg, supra note 12, at $206-07$.

100. See Filartiga v. Pena-Irala, 630 F.2d 876 (2d Cir. 1980). 
wisdom of such a power or its exercise, but implicit authorization of such conduct by governments in a charter of rights designed to provide enhanced protection to citizens seems somewhat strange.

The Charter also provides that any person charged with an offense has the right "if finally acquitted of the offence, not to be tried for it again and, if finally found guilty and punished for the offence, not to be tried or punished for it again." 101 It seems clear that the provision does not bar a second prosecution when the first prosecution was terminated prior to a final judgment.

Experience in the United States suggests that few prosecutors would consider trying a defendant again for the same offense after acquittal or conviction and punishment. There seems to be a greater tendency to seek a retrial where a mistrial has occurred. Where the mistrial was not caused by "manifest necessity" or the "ends of public justice," a retrial is prohibited under U.S. law, even if the first trial never concluded in a final judgment. ${ }^{102}$ If the mistrial was caused by the prosecution and the defendant objects, "manifest necessity" is unlikely to be found, ${ }^{103}$ and retrial is prohibited. In the absence of extraordinary circumstances, a prosecutor could not, for instance, withdraw the charges after a trial has commenced, even with permission of the court, and commence prosecution again at a later time. ${ }^{104}$

The language of the second clause of the provision may cause difficulty. It is difficult to conclude that a person has been "found guilty and punished" when he has been found guilty and absolutely discharged by the court, for example when the sentence is suspended or the defendant is put on probation. The defendant would, however, have a statutory right to plead autrefois convict, ${ }^{105}$ if retried under such circumstances, despite the fact that he has not been technically "convicted."106

The Charter provision does not clearly state whether a person may be prosecuted and convicted under federal law and provincial law for the same conduct. There are good grounds for arguing that successive prosecutions should be barred

101. Constitution Act, 1982, ch. $1, \S 11(\mathrm{~h})$. The 1979 Federal Proposals recommended the inclusion of a double jeopardy provision. Gibson, supra note 10, at 372 . Its absence from the Bill of Rights and earlier proposals had been criticized. Id. at 371 . The 1980 Proposals provided that anyone charged with an offense has the right "not to be tried or punished more than once for an offence of which he or she has been finally convicted or acquitted." 1980 Proposals, supra note $19, \S 11$ (f). A proposal to modify the language to prohibit retrial of anyone "found guilty of and punished for any act or omission constituting the offence," obviously designed to provide protection against prosecution for related offenses or for offenses substantially the same as the principal offense, failed. 47 JOINT COMMITTEE ProceEdings, supra note 16 , at 60 .

102. Illinois v. Somerville, 410 U.S. 458 (1973). United States Supreme Court cases involving double jeopardy are discussed in Hudson v. Louisiana, 450 U.S. 40 (1981).

103. See, e.g., Downum v. United States, 372 U.S. 734 (1963).

104. Cf. Crist v. Bretz, 437 U.S. 28 (1978); R. SAlhaNy, supra note 49, at 136-37.

105. The plea of "autrefois convict" is the legal counterpart at common law of "autrefois acquit," and the rule forbids a second trial for the same offense whether the accused at the former trial was acquitted or convicted. Johnson v. State, 62 A.2d 249, 250, 191 Md. 447, 450 (1948).

106. Criminal Code, CAN. REv. STAT. ch. C-34, \$ 535(5)(c) (1970);, R. Salhany, supra note 49, at 223-24. See generally Gautier, The Power of the Crown to Reinstitute Procedings after the Withdrawal or Dismissal of Charges, 22 CRIM. L.Q. 463 (1980). 
when the criminal justice system in each province is "to a large extent unitary." 107 It would be unjust to sentence a defendant more than once for the same conduct or require him to defend more than once for the same charge. Successive prosecution is permitted by the Constitution in the United States. ${ }^{108}$ Presumably, prosecution for different crimes arising out of the same transaction is not barred.

\section{E. Unreasonable Search or Seizure}

The Charter provides that "[e]veryone has the right to be secure against unreasonable search or seizure." 109 Its exact meaning is understandably unclear ${ }^{110}$ since similar language in the U.S. Constitution remains uncertain after almost 200 years. ${ }^{11}$ There is no reason to assume that Parliament intended to adopt the gloss placed upon the phrase "unreasonable searches and seizures". by the Supreme

107. P. HOGG, supra note 12, at 112. A unitary system is one that has one set of courts and prosecutors. Cf. 47 Joint Committee Proceedings, supra note 16, at 62.

108. Abbate v. United States, 359 U.S. 187 (1959); Bartkus v. Illinois, 359 U.S. 121 (1959).

109. Constitution Act, 1982, ch. 1, $\S 8$. The 1969 Proposals recognized and guaranteed "the right of the individual to be secure against unreasonable searches and seizures." 1969 PROPOSALS, supra note 22 , $\S 2$ (a), at 52. The language was endorsed in the 1972 JOINT COMMITTEE REPORT, supra note 19, and the Canadian Bar Association Proposals. The Bar Association went further and proposed a right to personal privacy, quoting with approval the Manitoba Law Reform Commission proposal:

(1) No person shall be subjected to unreasonable interference with her or his privacy.

(2) For the purpose of this section, a search, seizure or intentional interception of communication shall be deemed to be unreasonable interference unless lawfully made:

a. in accordance with an order made by a court of competent jurisdiction;

b. in accordance with a search warrant issued by a court of competent jurisdiction on reasonable grounds supported by adequate information describing the purpose of the search and who or what is to be searched.

c. in response to circumstances of such seriousness and urgency as to require and justify immediate action without the authority of such an order or warrant.

and in any event, every search, seizure, or interception of communications shall be effected with no more force or interference with privacy than is necessary to carry out the provisions of the order or warrant or to meet the seriousness or urgency of the circumstances.

TOWARDS A NeW CANADA, supta note 10, at 19.

The 1978 PROPOSALS included "the right to be secure against unreasonable searches and seizures." 1978 Proposals, supra note $16, \S 7$. The 1979 Federal Proposals added a "right against unreasonable interference with privacy." Gibson, supra note 10, at 372. The 1980 PROPOSALS were much narrower: "Everyone has the right not to be subjected to search or seizure except on grounds, and in accordance with procedures, established by law." 1980 Proposals, supra note $19, \$ 8$. The explanatory note indicates that the provision "derives in part from the U.N. Covenant." Id. at 16. Existing Canadian law is summarized in McConnell, supra, note 29. See generally Bracken, Federal Law Relating to Search and Seizure, 28 U.N.B.L.J. 53 (1974). In response to the recommendations of a number of witnesses, the government returned to the language of the earlier proposals. 36 Joint CommrtTee Proceedings, supra note 16, at 11 (1981).

110. For instance, it remains to be seen whether the courts will refuse to apply the exclusionary rule to the fruits of an illegal search. See Hogan v. The Queen, 48 D.L.R.3d 427 (1974), in which the Supreme Court of Canada refused to apply the exclusionary rule in a case arising under the CAN. BiLL OF RIGHTS, supra note 12 .

111. At first blush it would appear that the provision provides protection against searches of persons or places and against seizures of persons and things. But an amendment to alter the language to read "not to be subjected to unreasonable search and seizure of person or property" was unsuccessful. 46 JOINT CommitTee Proceedings, supra note 16, at 102, 108 (1981). In opposing the provision as unnecessary and possibly restrictive, the Deputy Minister of the Department of Justice argued that seizure of the person is covered by $\S 9$, the right not to be arbitrarily detained or imprisoned. Id. at 104-05 (statement of $\mathrm{Mr}$. Tasse). It was also argued by the government that the addition was unneeded and might preclude an interpretation that interceptions of aural communications are protected under the provision. Id. It would be difficult to argue that privacy itself is protected in view of the decision to reject the proposed amend- 
Court of the United States, but the rich judicial history of the fourth amendment in the United States can certainly provide a guide to the kinds of issues which will face the Supreme Court of Canada in interpreting the enigmatic clause. ${ }^{112}$ Presumably, a search or seizure can be unreasonable although permitted by statute. Otherwise, the change in language from the 1980 Proposals was meaningless. ${ }^{113}$ Likewise, there may be some searches which violate statutes or regulations, but which are not "unreasonable." 114 A wide variety of other issues can also be anticipated: What interests are protected? ${ }^{115}$ What constitutes a search? 116 What constitutes a seizure?117 What constitutes justification for a search or seizure: must there be "probable cause" or will a lesser standard suffice for all or some searches or seizures?"18 Can a search or seizure otherwise reasonable become "unreasonable" because of the manner in which it is conducted?"19 Do different tests of "unreasonableness" apply to searches of homes, ${ }^{120}$ cars, ${ }^{121}$ and closely regulated businesses? ${ }^{122}$ Are searches incident to an arrest per se reasonable, ${ }^{123}$ and if so, what is the scope of such a search? ${ }^{124}$

There are a host of other questions that will require resolution. It may be going too far to say that "concern over limitations upon the police powers to conduct searches and seizures have never been critical issues in Canada." 125 But the absence of both protection against unreasonable searches and seizures and an exclusionary rule in the Bill of Rights has produced a jurisprudence of search and

ment to $\S 7$ that would have expressly assured protection against arbitrary or unreasonable interference with privacy. See id. at 62,70 .

Mr. Justice McDonald points out that the French version speaks not only of searches and seizures, but also of rummaging ("les tovilles"). He also notes that "unreasonable" appears in the French version as "abusives" in §8, while "reasonable" in $\S \S 11(3)$ and 11(6) is expressed as "raisonnable" in the French, with no explanation for the difference in language. D. MCDONALD, supra note 37, at 29.

112. U.S. CONST. amend. IV:

The right of the people to be secure in their persons, houses, papers, and effects, against unreasonable searches and seizures, shall not be violated, and no Warrants shall issue, but upon probable cause, supported by Oath or affirmation, and particularly describing the place to be searched, and the person or things to be seized.

For a comparison of the American experience under the fourth amendment with Canada's experience without such a constitutional provision, see McConnell, supra note 29, at 158 .

113. See supra note 109.

114. See United States v. Caceres, 440 U.S. 741 (1979).

115. For the U.S. interpretation, see Katz v. United States, 389 U.S 347 (1967); Abel v. United States, 362 U.S. 217 (1960).

116. For the U.S. interpretation, see Smith v. Maryland, 442 U.S. 735 (1979); Cardwell v. Lewis, 417 U.S. 583 (1974); Hester v. United States, 265 U.S. 57 (1924).

117. For the U.S. interpretation, see United States v. Mendenhall, 446 U.S. 544 (1980). In particular, the issue of the legality of "stops and frisks" may become significant. See D. MCDONALD, supra note 37, at 65.

118. For the U.S. interpretation, see United States v. Brignoni-Ponce, 422 U.S. 873 (1975); Adams v. Williams, 407 U.S. 143 (1972).

119. For the U.S. interpretation, see Payton v. New York, 445 U.S. 573 (1980); Ker v. California, 374 U.S. 23 (1963).

120. For the U.S. interpretation, see Vale v. Louisiana, 399 U.S. 30 (1970).

121. For the U.S. interpretation, see Chambers v. Maroney, 399 U.S. 42 (1970).

122. For the U.S. interpretation, see United States v. Biswell, 406 U.S. 311 (1972).

123. For the U.S. interpretation, see United States v. Robinson, 414 U.S. 218 (1973).

124. For the U.S. interpretation, see Chimel v. California, 395 U.S. 752 (1969).

125. Katz, Reflections on Search and Seizure and Illegally Seized Evidence in Canada and the United States, 3 CAN.-U.S. L.J. 103, 118 (1980). 
seizure that provides little help in resolving the issues which will soon confront Canadian judges. ${ }^{126}$

A case such as the one involving the "Fort Erie" raid provides an example of Canadian jurisprudence under the Bill of Rights. In 1974, Canadian police officers conducted a drug raid in a Fort Erie hotel. In the course of their investigation, they searched virtually all of the 115 patrons on the premises, including 35 women patrons who were stripped and subjected to vaginal and rectal examinations. ${ }^{127}$ The police had no warrant but had reason to suspect that there were drugs in the hotel. A special Royal Commission held that (1) the searches were lawful because police are entitled to enter forcibly and conduct a search of a place other than a dwelling house without a warrant if they have reasonable grounds to believe that the entered premises contain unlawful narcotics, and (2) the police can lawfully search everyone found on such premises, including those not reasonably suspected of possessing narcotics. ${ }^{128}$ It is clear that entry into the premises without a warrant under such circumstances would be "unreasonable" under American precedents, ${ }^{129}$ and even if a warrant authorized search of the hotel, search of its occupants would be unreasonable unless they were named in the warrant. ${ }^{130}$ Whether the Canadian courts will reach a similar conclusion under the new Charter provision is less sure.

Certainly, careful scrutiny will be given to writs of assistance, general search warrants which can be obtained by designated officers of the RCMP and certain other federal agents charged with the enforcement of the Customs Act, ${ }^{131}$ Excise Act, ${ }^{132}$ Narcotic Control Act, ${ }^{133}$ and Food and Drugs Act. ${ }^{134}$ One of the primary reasons for the American fourth amendment was colonial opposition to writs of assistance, particularly those used to enforce customs laws. ${ }^{135}$ In Canada, writs of assistance authorize the holders to enter homes whenever they have reasonable belief that a search will reveal evidence of drugs, customs violations, or excise violations; the writ need not relate to any specific offense, and it continues to be in force throughout the career of the officer to whom it is issued. ${ }^{136}$ It is difficult to imagine how breaking into a home without prior judicial approval in the absence of exigency by an officer who holds a writ issued years earlier could be held to be

126. See R. SAlhaNy, supra note 49, at 45-56. See generally Gibson, Illegally Obtained Evidence, 31 U. ToR. FAC. L. REV. 23 (1973); Spiotto, The Search and Seizure Problem-Two Approaches: The Canadian Tort Remedy and the U.S. Exclusionary Rule, 1 J. POLICE SCI. AND AD. 36 (1973).

127. Borovoy, The Powers of the Police and the Freedoms of the Citizen, in THE PRACTICE OF FREEDOM 425 (1979).

128. Report of the Royal Commission on the Conduct of Police forces at Fort ERIE on THE 11TH OF MAY, 1974 (1975); Borovoy, supra note 127, at 425.

129. Agnello v. United States, 269 U.S. 20 (1925).

130. Ybarra v. Illinois, 444 U.S. 85 (1979).

131. Customs Act, Can. Rev. Stat., C-58, $\$ 139$ (1952).

132. Excise Act, Can. Rev. Stat. C-99, $\$ \S 78,79$ (1952).

133. Narcotic Control Act, Can. Stat. C-35, § 10(3) (1960-61).

134. Food and Drug Act, Can. Stat. C-38 (1952-53) amended by Can Stat. C-37, § 36(3) (1960-61).

135. Katz, supra note 124 , at $110,125$.

136. R. SalhaNy, supra note 49, at 56. See generally Katz, supra note 125, at 124; Parker, The Extraordinary Power to Search and Seize and the Writ of Assistance, 1 U. BRIT. COLUM. L. REV. 688 (1963); Trasewick, Search Warrants and Writs of Assistance, 5 CRIM. L.Q. 341 (1963); Comment, Writs of Assitance in Canada, 9 AlBerta L. Rev. 386 (1971). 
"reasonable," even if the officer reasonably believes contraband will be found. ${ }^{137}$

\section{III}

\section{The Exclusionary Rule}

The power granted to courts to enforce the guaranteed rights may be the most important provision of the Charter:

24. (1) Anyone whose rights or freedoms, as guaranteed by this Charter, have been infringed or denied may apply to a court of competent jurisdiction to obtain such remedy as the court considers appropriate and just in the circumstances.

(2) When, in proceedings under subsection (1), a court concludes that evidence was obtained in a manner that infringed or denied any rights or freedoms guaranteed by this Charter, the evidence shall be excluded if it is established that, having regard to all the circumstances, the admission of it in the proceedings would bring the administration of justice into disrepute. ${ }^{138}$

The provision responds to those who have urged that the most important problem in the protection of civil liberties is not the existence of generally accepted rights, but the existence of adequate remedies for their violation. ${ }^{139}$

The first subsection simply authorizes application to a court of competent jurisdiction and grants discretion to the court to provide an "appropriate and just" remedy under the circumstances. It is unclear which courts are "courts of competent jurisdiction." Furthermore, it is difficult to determine the meaning of an "appropriate remedy" as applied to criminal proceedings. Presumably, the authority to issue an extraordinary writ or an injunction might be appropriate in certain cases. It has been suggested that granting an acquittal or a new trial might

137. Two government officials, the Acting Minister of Justice, Mr. Kaplan, and the Senior Counsel, Public Law, Mr. Jordan, recognized that writs of assistance as they have been used in the past may be unreasonable under the provision. 41 Joint Commrttee Proceedings, supra note 16, at 14 (statement of Mr. Kaplan); id., vol. 46, at 108 (statement of Mr. Jordan).

138. Constitution Act, 1982, ch. 1, § 24. The 1978 Proposals provided:

Where no other remedy is available or provided for by law, any individual may, in accordance with the applicable procedure of any court in Canada of competent jurisdiction, request the court to define or enforce any of the individual rights and freedoms declared by this Charter, as they extend or apply to him or her, by means of a declaration of the court or by means of an injunction or similar relief, accordingly as the circumstances require.

1978 Proposals, supta note $16, \S 24$. The 1979 Federal Proposals provided that "where no other effective recourse or remedy exists, courts empowered to grant such relief or remedy for a violation of Charter rights as may be deemed appropriate and just in the cicumstances[sic]." Gibson, supra note 10, at 385. The 1980 PROPOSALS rejected such an approach: "No provision of this Charter, other than section 13 , affects the laws respecting the admissibility of evidence in any proceeding or the authority of Parliament or a legislature to make laws in relation thereto." 1980 Proposals, supra note $19, \S 26$. The explanatory note indicated that the section "would make it clear that no provision of the Charter other than the sections respecting self-incrimination (section 13) would affect existing or future laws respecting the admissibility of evidence." Id. at 24. Opposition to proposed $\S 26$, voiced by the Canadian Bar Association, the Chief Commissioner of the Canadian Human Rights Commission, and others persuaded the government to drop the section. 36 JoInT Commitee Proceedings, supra note 16, at 19 (1981). Assertions of the need for remedies for breach of Charter rights by the Canadian Civil Liberties Association, the Canadian Jewish Congress, and others persuaded the government to propose $\S 24(1)$. Id. The second clause, the exclusionary rule, was proposed later. As originally drafted, it provided that "evidence may be excluded ...." The government agreed to substitute "shall" for "may," and the provision was approved by the Committee in its present form. Id., vol. 48, at 120-21 (1981) (emphasis added).

139. Mewitt, Entrenching the Enforcement of Rights, 23 CRIM. L. Q. 129, 129 (1981). 
be the appropriate remedies to enforce rights in some circumstances. ${ }^{140}$

The most surprising innovation is the inclusion of a narrow exclusionary rule when only a year earlier the idea apparently had been rejected. ${ }^{141}$ The Canadian Supreme Court decisions in The Queen $v$. Wray, ${ }^{142}$ permitting the admission of a murder weapon found as a result of an involuntary confession, and Hogan $v$. The Queen, ${ }^{143}$ in which breathalyzer test results obtained in violation of the defendant's right to the assistance of counsel were admitted, had effectively rejected the concept of a rule excluding evidence obtained illegally. The obvious purpose of section 24(2) is to introduce the concept of excluding tainted evidence in the limited circumstances where the admission of the evidence "would bring the administration of justice into disrepute." The provision clearly does not go as far as the American rule, which automatically excludes evidence obtained unlawfully, no matter how "mild," "technical," or "inadvertent" the police conduct. ${ }^{144}$ Nor would exclusion hinge solely upon the "good faith" of the officials who violated the Charter ${ }^{145}$ or on the "substantiality" of the violation, ${ }^{146}$ although these might constitute factors relevant to the issue of the effect of admission on the reputation of the system for the administration of justice. Instead, the Charter provision focuses on the effect of the admission of the evidence upon the process of justice. The approach is one of ensuring the "imperative of judicial integrity."147

The test of whether admission of evidence would "bring the administration of justice into disrepute" is the same as that recommended by the 1977 Report of the Law Reform Commission. The Commission proposed that:

[I]n determining whether evidence should be excluded under this section, all the circumstances surrounding the proceedings and the manner in which the evidence was obtained shall be considered, including the extent to which human dignity and social values were breached in obtaining the evidence, the seriousness of the case, the importance of the evidence, whether any harm to an accused or others was inflicted willfully or not, and whether there were circumstances justifying the action, such as a situation of urgency requiring action to prevent the destruction or loss of evidence. ${ }^{148}$

The Commission made it clear that its intent was to protect the integrity of the

140. Gibson, supra note 10 , at 384 . It was apparently understood within the Joint Committee that a court would clearly have jurisdiction to award compensation. 48 JOINT COMMITTEE PROCEEDINGS, supra note 16 , at 121 .

141. See supra note 138 .

142. The Queen v. Wray, 11 D.L.R.3d 673 (Can. 1970).

143. Hogan v. The Queen, 48 D.L.R.3d 427 (Can. 1974).

144. See, e.g., Whitely v. Warden, 401 U.S. 560 (1971); Spinelli v. United States, 393 U.S. 410 (1969). See generally Kamisar, A Defense of the Exclusionary Rule, 15 CRIM. L. BuLL. 5 (1979). The United Kingdom has recently rejected such an automatic rule of exclusion. Report of the Royal Commission on Criminal Procedure 112-18 (1981). Some witnesses proposed an automatic rule of exclusion. See, e.g., 22 JOINT COMmittee Proceedings, supra note 16, at 108 (1980). Cf. id. vol. 39, at 57 (1981).

145. Cf. Stone v. Powell, 428 U.S. 465, 499 (1976)(Burger, J., concurring); United States v. Williams, 622 F.2d 830 (5th Cir. 1980), cert. denied, 449 U.S. 1127 (1981).

146. Proposals for using "substantiality" of the violation as the criterion for exclusion have been proposed as a rule that would permit the balancing of several factors such as the extent of the deviation from the law; the good faith of the official; the impact on deterrence if the evidence was excluded or admitted. A Model Code of Pre-Arraignment Procedure, \$ 290.2 (1975).

147. See Mapp v. Ohio, 367 U.S. 643, 659 (1961). But see Stone v. Powell, 428 U.S. 465 (1976)(the imperative of judicial integrity has limited force as justification for the exclusion of highly probative evidence).

148. Law Reform Commission of CaNada, Report on Evidence, tit. IV, pt. I, \$ 15, at 22 (1977). 
adjudicative process, not to control the police, and that it rejected an absolute exclusionary rule. Instead, it sought to give judges the right in "exceptional cases" to exclude evidence unfairly obtained. ${ }^{149}$

It seems unlikely that there will be many instances in which the "fruit of the poison tree doctrine" 150 will be applied, or where technical or inadvertent violations will result in exclusion. The obvious difficulty of balancing factors that are different in kind, and the judicial reluctance to exclude reliable evidence reflected in the existing case law, suggest that the operation of section 24(2) may not be significantly different from the discretion exercised in the courts of the United Kingdom. ${ }^{151}$ It would not be surprising if exclusion were limited to cases of willful, gross violations. ${ }^{152}$ The exclusion of evidence may occur infrequently, particularly in serious cases, but it may nevertheless occur more often than under a rule that excludes only evidence "the admissibility of which is tenuous and whose probative force in relation to the main issue before the Court is trifling." 153 The importance of the provision is indicated by the fact that neither Parliament nor provincial legislatures can opt out of its operation. ${ }^{154}$

\section{IV}

\section{The Substance of the Constitutional Protections}

\section{A. Areas Left Unprotected}

It is difficult to predict the degree to which the constitutional protections afforded by the Charter to persons accused of crime will provide realistic and significant safeguards against the dangers of government abuse of power. The Charter obviously provides important protections, but it simultaneously ignores some contemporary, crucial issues concerning the appropriate balance between the state and the individual in criminal prosecutions.

Obviously, no charter of rights should attempt to deal with all issues of criminal procedure, but the observer is struck by the high degree to which specific

149. Id. at 61-62. The concept also is responsive to the position tersely stated by the President of the Vancouver People's Law School Society, Mrs. Diana Davidson: "It is particularly important that we not supply the police with a document which in effect says that they may violate the human rights with impunity." 32 Joint Committee Proceedings, supra note 16, at 13.

150. The doctrine of "fruit of the poisonous tree" was first enunciated in Silverthorne Lumber Co. v. United States, 251 U.S. 385, 392 (1920): "The essence of a provision forbidding the acquisition of evidence in a certain way is that not merely evidence so acquired shall not be used before the Court but that it shall not be used at all." The phrase was first used to describe the doctrine in Nardone v. United States, 308 U.S. 338 (1939).

151. See Report of the Royal Commission on Criminal Pracedure, supra note 144, at 63-64, $112-17$ (1981).

152. See A Model Code of Pre-Arraignment Procedure \& 290.2(3) (1975): "A violation shall in all cases be substantial if it was gross, willful and prejudicial to the accused." It has been argued that $\S 8$ prohibits unreasonable searches by private persons as well as by police. D. MCDONALD, supra note 37 , at 45. If so, it is doubtful if many such seizures should warrant exclusion under the test of $\S 24(2)$.

153. The Queen v. Wray, 11 D.L.R.3d 673, 689-90 (Can. 1970). The Charter might also form a "standard against which government performance may be evaluated in Parliament, the press and in political discussion generally," making government "more sensitive to civil libertarian values in framing new law and administrating existing laws." P. HoGG, supra note 12 , at 443 . It also performs an educational value of inculcating into each new generation a perception of preferred values.

154. Constitution Act, 1982, ch. 1, § 33. 
protections are given to the citizen in areas where the danger of abuse by the state is relatively slight, such as the right to be presumed innnocent, the right to have a hearing before an impartial tribunal, the right to be tried within a reasonable time, the limited protection provided against double jeopardy, and protection against ex post facto laws. These are important rights, and deserve protection, but they are unlikely to be the focal point of confrontation between the individual and the state in the twenty-first century. Like the rights to confrontation and compulsory process, which are surprisingly absent from the Charter, ${ }^{155}$ these rights are the stuff of an earlier history which fortunately are now accepted as fundamental. In a nation with a common law tradition, these rights would probably be respected even if not reflected in a written document. They are not likely to be regarded as the primary areas where government abuse of power is most likely to occur.

In contrast, in areas where the danger of government abuse is great, the constitution provides few protections. The document is silent on matters such as the rights of a recalcitrant suspect from whom the police are attempting to extract a confession and the rights of a suspect when asked to participate in pretrial identification procedures. Consider the protection against abuse needed by an indigent member of a minority group who is subjected to an incommunicado interrogation without access to counsel, while a mafia chieftain stands no such risk because of his financial ability to obtain counsel to protect himself. It is unclear whether the constitution makes provision for the rights of an individual to be free from electronic surveillance. The protection of papers from unreasonable search and seizure is less meaningful if one's privacy can be invaded by bugs and wiretaps. ${ }^{156}$

It is nice to know, too, that a person will be informed without unreasonable delay of the offense with which he is charged, and tried within a reasonable time. But such a right is unhelpful if the counsel provided for him by legal aid is unable to locate the witnesses he seeks, and the government is not prepared before trial to assist him by granting him access to favorable evidence. It is particularly discouraging to realize that the citizen's right to counsel at trial may depend upon the financial capacity of the province in which he resides rather than upon the Constitution of Canada.

The effect of the Constitution in these areas will depend, in part, on the interpretation of various provisions. Much will depend upon the manner in which the Supreme Court of Canada interprets section 7 of the Charter, providing that no one will be deprived of the right to liberty except in accordance with the principles of fundamental justice. This provision could be interpreted to assure that the protections accorded Canadians in criminal prosecutions are those that a society of the 1980's thinks are fundamental, not those which were the source of controversy two centuries ago. Thus, rights such as the right to counsel at trial might be protected as required by the "principles of fundamental justice." A broad interpretation of the protection against unreasonable search and seizure could provide protection for the privacy needs of our century as well as for the privacy needs that existed in an era in which telephones, parabolic microphones, and pen registers

155. A proposal to include such protections was defeated. 47 JoInT CommitTe Proceedings, supra note 16 , at 69,73 .

156. Protection may be provided by $\$ 8$ of the Charter. See supra note 111 . 
were unknown. On the other hand, a narrow interpretation of the exclusionary rule could reduce the Charter to a noble statement of principles to which all pay lip service, but to which no court turns when the going gets rough. ${ }^{157}$

\section{B. The Charter As a Consensus}

A foreign observer can hope that the courts will approach the Charter with more enthusiasm for civil liberties than has been evidenced in decisions interpreting the Bill of Rights. ${ }^{158}$ Whether the courts will take this approach may depend in part on their perception of the inherent legitimacy of the document, that is, the extent to which it reflects a national consensus concerning basic values as distinguished from a political compromise effected by the party in power to accomplish other objectives. ${ }^{159}$

Unfortunately, the record is not clear on the extent to which the documents genuinely reflect a popular will to limit legislative and executive power in order to protect certain rights. The polls reported that the people wanted a charter; the polls were less clear, however, about whether the people knew what they were and were not receiving. There is a difference between a bill of rights hammered out in a constitutional convention or adopted after proposals are debated in state or provincial legislatures over a period of years, and a bill of rights drafted by the party in power in Parliament.

This difference is highlighted when the party in power presents a reasonably narrow statement of rights in one year, and is prepared to alter them significantly the following year, as occurred in Canada. In 1980, the Charter would have provided protection against searches and seizures, detentions, and denial of bail only when they were not carried out "on grounds, and in accordance with procedures established by law."160 In 1981, the provisions were changed so that, even if authorized by law, a search and seizure is impermissible if "unreasonable";161 a detention must not be "arbitrary"; 162 and reasonable bail cannot be denied

157. Cf. Laskin, supra note 19 , at $343-44$.

158. Professor Tarnopolsky has admirably described the narrow interpretation of the last two decades. See sources cited supra note 10.

159. It seems reasonably clear that the 1980 PropOSALS were subject to such criticism. The Minister of Justice stated:

We were on the horns of a dilemma when we started and now we want to secure the support of as many provinces as possible. We have introduced a bill of rights to be entrenched in the constitution that was meeting a lot of the objection from the Ministers during the meeting I had with them during the summer.

Despite a very conciliatory attitude on our part, the provinces who were opposed in the summer to the whole process did not offer any support to the Bill of Rights whatever, after we came in public, even if they had some great interest in the summer to have the Charter of Rights inscribed. I do think that the ones who were the most opposed in principle, I guess, it was Manitoba, Mr. Lyons who always said he did not want at all the Bill of Rights in the constitution entrenched.

But most of the other provinces had kind of a sympathy to it and did not want to oppose it squarely.

We introduced that watered down Bill of Rights in October but that did not change the attitude of those who were opposing.

37 Joint Committee Proceedings, supra note 16, at 25-26 (1980); see also id. vol. 50, at 51, 70 (1981).

160. 1980 Proposals, supra note $19, \$ \S 8,9,11$ (d).

161. Constitution Act, 1982, ch.1, $\$ 8$.

162. Id. $\$ 9$. 
without "just cause." 163 In 1981, it was concluded that a person charged with an offense should not be compelled to be a witness in proceedings against him in respect to that offense; ${ }^{164}$ that an accused has a right to be informed of his right to counsel; ${ }^{165}$ and that an accused has a right to a jury trial where the maximum punishment for the offense is five years or more. ${ }^{166}$ Such rights were apparently not regarded as fundamental a year earlier since they were not included in the proposals. In 1980, the proposals made it clear that no provision of the Charter would affect existing or future laws respecting the admissibility of evidence; ${ }^{167}$ yet in the next year the Charter included an exclusionary rule. ${ }^{168}$ Authority to opt out is given by the 1982 Charter, where a year earlier no similar provision was included in the document. ${ }^{169}$ The legitimacy of the document as a fundamental expression of a social contract is not improved by the changes in "fundamental" rights, by recognition that several of the proposals in 1980 reflect retreats from proposals previously made, nor by charges that the process of enactment was "tainted by unilateralism."170

Understandably, the final draft of the Charter benefitted from extensive Parliamentary hearings in 1980 and $1981^{171}$ and from wide public discussion. Some of the provisions that finally emerged, such as the protection from unreasonable searches and seizures, while not present in the same form in the 1980 proposals, had been proposed at least as early as 1969.172 Few observers on the American side of the border would deny that the "Legal Rights" provisions of the 1982 Charter are a significant improvement over the 1980 Proposals. It can presumably be argued that the 1980 draft was a "law and order" document that retreated, for temporary political reasons, from earlier understandings concerning the degree to which the rights of the citizen deserved protection. ${ }^{173}$ The 1981 document more accurately reflects the growing consensus concerning the proper balance between citizens and the state, a balance reflected in the proposals considered before 1980 .

In addition to playing the role of arbiter of federalism, the Supreme Court of Canada has been presented with the challenge of assuming the constitutional role of protector of the rights of the citizenry. It should welcome this opportunity. The Charter itself is a significant step forward. As confidence in a written charter of rights develops, so may the desire to expand the constitutional protection of individual rights.

163. Id. $\S 11(\mathrm{e})$.

164. Id. $\S 11(\mathrm{c})$.

165. Id. $\S 10(\mathrm{~b})$.

166. Id. $\S 11(\mathrm{f})$.

167. 1980 PROPOSALS, supra note 19 , at $\S 26$. An exception was made for the protection against selfincrimination in $\S 13$.

168. Constitution Act, 1982, ch. 1, § 24(2).

169. Compare id. $\S 33$ with 1980 PROPOSALS, supra note 19.

170. Laskin, supra note 19 , at 347 .

171. The Joint Committee, composed of 10 members from the Senate and 15 from the House of Commons, held 106 meetings on 56 sitting days for a total of 267 sitting hours, considering submissions from 914 individuals and 294 groups. 57 JoINT COMMrTtee ProceEdings, supra note 16, at 5 (1981).

172. See 1969 Proposals, supra note 22, at 52.

173. See supra note 159. 